\title{
Insider Trading as a Signal of Private Information
}

\author{
Aswath Damodaran \& Crocker H. Liu \\ New York University
}

There is substantial evidence that insider trading is present around corporate announcements and that this insider trading is motivated by private information. Using real estate investment trusts that choose to reappraise themselves as our sample, we establish that the appraisals contain information, but find no market response to the public announcement of this information in these appraisals. We consider two possible explanations for this inconsistency: the first that the appraisal information is not highlighted in earnings reports and hence remains unobserved; and the second that insiders trade on the appraisal information in the time that elapses between the appraisal and its public announcement. We find strong support for the second hypothesis, with insiders buying (selling) after they receive favorable (unfavorable) appraisal news, especially for negative appraisals. We also find that positive (negative) appraisals and net insider buying (selling) elicit significant positive (negative) abnormal returns during the appraisal period.

There is substantial evidence that insider trading is present around corporate announcements and that this insider trading is motivated by private information. Studies also document that insiders who have access to private information can outperform the market. ${ }^{1}$ In the sequence of information events starting with the revelation of the private information to insiders followed by revelation of this information to the public and then by secondary reports from analysts, researchers have focused on the public announcement stage, with the period preceding these announcements examined for evidence of insider trading and abnormal price reaction. Most tests of insider trading have been indirect because

\footnotetext{
${ }^{1}$ Jaffe (1974a, 1974b) and Finnerty (1976) examine abnormal returns around months in which insiders trade intensively and find support for the finding that there are substantial positive (negative) returns following insider buying (selling). Givoly and Palmon (1985) extend these studies by correlating insider trading with subsequent news releases and find that insiders do not trade in anticipation of news releases. In contrast to this, Copeland and Lee (1988), Hirschey and Zaima (1989), and John and Lang (1991) find evidence that significant insider trading is present around corporate announcements. Keown and Pinkerton (1981) also report substantial insider trading beginning one month before the announcements of corporate takeovers and find that one half of the price reaction takes place before the announcement.
} 
researchers have been stymied by the fact that the timing of when private information is revealed to insiders in the firm, as well as the content of this information, is generally unobservable. ${ }^{2}$

One feature of the current study is that we are able to obtain a private information attribute that is available and known only to insiders as of a certain month. This affords us the opportunity to study the initial stage in the information dissemination process when private information is revealed to insiders and to explore how insiders use this information prior to the public announcement of this information. More specifically, we are able to examine directly the link between insider trading and abnormal price reaction to the sequence of information revelation starting from the time that information is revealed to insiders, continuing on through to the public announcement of this information, and ending when this information is repackaged and revealed to the general public.

We use data on equity real estate investment trusts (EREITs) and real estate operating companies as a vehicle to test the above hypotheses. EREITs and real estate companies offer a unique setting to test these conjectures because real estate investment trusts (REITs) sometimes use outside appraisers to revalue the properties that they own. The resulting appraised values as well as the month of the appraisal are reported in subsequent earnings announcements. These appraisals are also summarized and reported by external services to subscribing investors at a later date. Since a substantial time period elapses between the appraisal (the private information attribute) and the public announcement of appraisal values, there is a significant period of time during which insiders in the firm know the appraisal value while outsiders do not. Consequently, there is an opportunity for insiders to take advantage of this private information.

The process by which firms choose to have themselves appraised and the nature of the appraisal itself raises some critical issues that we examine in this article. First, insiders in REITs choose whether they will be appraised, when they will be appraised, and who will appraise them, giving rise to a clear selection bias. However, it also raises interesting questions about whether insiders can successfully predict when their companies are undervalued, and whether they use the appraisals as vehicles to make excess returns. Second, real estate appraisers carry out some of the functions that brokerage house analysts provide for other stocks, with two key differences: they work for the firm, and they have access to private information from the firm. By examining the results of the appraisals and their impact on market prices, we may be able to shed some light on whether this analysis has value to investors in the stock. Third, by examining differences in market reaction to insider trading accompanied by an appraisal

\footnotetext{
${ }^{2}$ One exception is the Cornell and Sirri (1992) study of insider trading in Anheuser-Busch's 1982 tender offer for Campbell Taggart. They find that insider trading had a significant impact on the market price and increased both trading volume and liquidity.
} 
to insider trading alone, we can shed some light on whether the public is more likely to believe an insider trading signal when it is accompanied by an appraisal/audit. This has a direct bearing on whether signaling models with insiders as players must be extended to include analysts and auditors. Since signaling assumes that insider trades are observable, our measures of insider trading are based upon SEC filings, which can be accessed by market participants.

In the first stage, we test the hypothesis that insider holdings increase in response to "good news" private information, which in turn is hypothesized to elicit a positive price response. ${ }^{3}$ The magnitude of this positive price response is posited to become more intense the larger the increase in the level of insider holdings. Conversely, insider holdings are hypothesized to decrease in response to "bad news" private information and this in turn is conjectured to elicit a negative price response. In addition to this, we examine the second stage in the sequence of information revelation, when the information is made public, to see if there is a market reaction to the public announcement of this private information and whether this reaction is related to the volume of insider trading preceding the announcement date. Finally, we examine the third stage in the information dissemination process, wherein public information is analyzed and repackaged in brokerage house reports, to see whether reports by advisory services possess the capacity to act as a secondary signal as well as influence market prices. $^{4}$

In examining whether insider trading acts as a signal of private information, we first establish that appraisals have informational value. This is accomplished by analyzing the composition of the appraised REITs in terms of the number of properties they own, and the number of regions and states that they operate in, and relating this portfolio composition to the divergence of appraised value from market value. Next, we evaluate the market's response to the public disclosure of these appraisals in earnings announcements and find that appraisals do not elicit a consistent price response from financial markets [i.e., positive (negative) appraisals are not accompanied by positive (negative) abnormal returns]. This finding is not necessarily inconsistent with our finding that appraisals have informational

\footnotetext{
3 John and Lang (1991) and John and Mishra (1990) hypothesize that the price reaction that takes place prior to the public announcement of information can be explained by a signaling model that allows insiders to change their holdings conditional on the arrival of new private information and that the resulting change in level of insider holdings in the firm is one of the signals available to convey this private information to the market. ${ }^{4}$ There is little consensus on whether investment advisory services that analyze and repackage public information have the capacity to earn excess returns or influence market prices. For example, Weinstein (1977) notes that changes in bond ratings occur several months after the capital markets have responded to fundamental changes in the bond's quality and that the ratings change itself does not cause changes in bond yields. In contrast, Copeland and Mayers (1982) examine the performance of stocks in different Value Line ranking classes, which are based on public information, and find evidence that these rankings have some power in predicting future returns.
} 
value, since there are at least two possible explanations that are consistent with this phenomena: (1) the first is that the appraisal information is not highlighted in earnings reports and hence remains unobserved; and (2) the second is that insiders trade on the appraisal information in the time that elapses between the appraisal and its public announcement. We reject the first hypothesis since there is no market reaction to the announcement of the appraisal information by Audit Realty, an investment information service that follows REITs.

In contrast to this, we find strong support for the second hypothesis, which is consistent with our signaling story. The evidence suggests that insiders take advantage of their private information (on appraisals), buying (selling) after favorable (unfavorable) news is received by them before that information is made public. However, although the level of insider holdings increases (decreases) given private information that is "good (bad) news," the market reaction to this signal is not symmetrical in a statistical sense. We find evidence that unfavorable appraisals are followed by negative abnormal returns in the month of the appraisal as well as in the time period between the appraisal month and the public announcement date. Favorable appraisals were also followed by positive abnormal returns in the appraisal month, but the returns are much smaller and less significant. We attribute this difference in market behavior to the bias in the appraisal process, since insiders in REITs that choose to be reappraised probably expect to receive a favorable appraisal and are surprised when they do not. We confirm this by examining insider filings with the SEC around the reappraisal month and find that there is substantially more insider buying than selling before insiders receive the appraisals (whether positive or negative), and that this pattern is dramatically reversed if insiders receive a negative appraisal. We also find that the abnormal returns in the appraisal period are strongly influenced by both the nature of the appraisal and the net volume of insider trading (insider buying - insider selling), with positive (negative) appraisals and net insider buying (selling) eliciting significant positive (negative) returns.

This article is developed and presented in four sections. In Section 1, we provide a background on the special features of REITs and the process of value reappraisal as well as a summary of existing research relating to REITs. In Section 2, we discuss the informational content of appraisals including how appraisers' estimates of value differ from those of stock analysts and why appraisals have informational value. In Section 3, we describe the sample and methodology used in the study. Our study includes 54 equity and hybrid REITs and real estate companies, for which we have reappraisal data starting in 1982 and ending in 1989. Results of our analysis are presented in Section 4. 


\section{Institutional Background and Review of REIT Literature}

\section{Background on Real Estate Investment Trusts}

Real estate investment trusts (REITs) came into existence on January 1, 1961, as an amendment to the Internal Revenue Code (Sections 856-858). Under this amendment, a REIT is not taxed on distributed taxable income if it satisfies certain provisions. These requirements include: (1) at least 95 percent (90 percent prior to 1980) of net annual taxable income must be distributed to shareholders; (2) at least 75 percent of annual gross income must come from rents, mortgage interest, gains from selling real estate, and dividends from investing in other REITs; (3) at least 75 percent of all assets must consist of real estate, mortgages on real estate, shares of other REITs, cash or government securities; (4) at least 95 percent of the REIT's gross income must come from items qualifying under the 75 percent income test, dividends and interest income, and gains from the sale of stock and other securities; ${ }^{5}(5)$ at least 100 shareholders must exist with no more than 50 percent of the shares held by five or fewer shareholders; (6) it must elect to be treated as a REIT; (7) real property must not be held primarily for sale in the ordinary course of business (gains from the sale of property held for less than four years must comprise less than 30 percent of gross income); and (8) trustees, directors, or employees of a REIT are restricted from actively managing or operating REIT property, although they are permitted to make property decisions if such decisions relate to the business of the REIT itself. These regulations are designed to ensure that REITs will be passive investment vehicles. If these provisions are met, then income is taxed only at the shareholder level. However, the trust is prohibited from passing through any operating losses to shareholders as a tax credit. $^{6}$

Real estate companies (RECOs), in contrast to REITs, do not function as passive investment vehicles. As such, RECOs are subject to double taxation except for those companies that are structured as publicly traded master limited partnerships. A real estate company is defined in the present study as

\footnotetext{
${ }^{5}$ For the 95 percent test of income, an additional 20 percent of income must be either passive or qualified under the 75 percent rule.

${ }^{6}$ The unique characteristics associated with REITs have allowed researchers to use REITs as a controlled alternative to the standard corporation in investigating a variety of issues. Chiang, Ling, and Venkatesh (1989) use the 95 percent taxable income payout requirement to test whether an information asymmetry cost exists for REITs when earnings and dividend announcements are separated from each other. Howe and Shilling (1988) use the fact that REITs do not pay any corporate taxes to examine several hypotheses concerning the market reaction to announcements of new security issues. Allen and Sirmans (1987) examine whether REIT mergers exhibit the same pattern of wealth distribution as corporate mergers given that the 75 percent passive income restriction for REITs rules out some classic corporate merger motives such as production synergy and monopolistic power. Palmon and Seidler (1978a, 1978b) and Hite, Owers, and Rogers (1984) investigate if market inefficiencies exist with respect to the current value reporting of real estate companies and real estate spin-off announcements, respectively.
} 
all real estate enterprises that are not structured as REITs and includes firms that develop, own, and/or manage a portfolio of real properties either on a sole ownership or partnership basis. Unlike REITs, RECOs are not constrained in the number of properties that can be sold in a given year, do not have to pay 95 percent of their earnings as dividends, and can engage in construction and development as well as any other type of real estate activity.

\section{Real Estate Appraisals: The Process}

In addition to the preceding characteristics of a REIT, some REITs as well as real estate companies hire professional appraisers to estimate a current value for their property holdings. This disclosure of current aggregate property value per share on fully diluted shares in REIT reports is a practice not followed by standard corporations and allows one to use appraised values as a private information attribute. ${ }^{7}$ To obtain current value, professional appraisers rely primarily on the income approach and to a lesser extent on the direct sales comparison approach in appraising income properties. The income approach to value initially involves estimating the net before-tax cash flows once normalized operations have occurred, where normalized operations are defined as property operations after the level of occupancy for the project is at least equal to that for the market as a whole. Next, a ratio known as the capitalization rate, which is analogous to the reciprocal of the price-earnings $(\mathrm{P} / \mathrm{E})$ multiple, is divided into the normalized before-tax net operating income to obtain a present value. This cap rate is estimated from comparable properties that have sold for which the analyst has information on the sales price and the net operating income. The appraiser examines the range of cap rates associated with the comparable properties and makes a judgment as to which rate is the most appropriate for the subject property. ${ }^{8}$ The direct sales comparison approach to value, like the income approach, relies on the sale of comparable properties. The intuition underlying this approach is that an

\footnotetext{
${ }^{7}$ However, from 1979 to 1984 , certain large publicly held corporations did report supplemental information to conform with Accounting Series Release (ASR) 190 and FASB Statement No. 33, which called for the disclosure of the estimated replacement cost of physical assets in 10K reports. ASR 190/FASB No. 33 was rescinded in part because financial analysts and investors were not using current cost data. For example, an Arthur Young \& Co. survey (reported in The CPA Journal, ' However, from 1979 to 1984, certain large publicly held corporations did report supplemental information to conform with Accounting Series Release (ASR) 190 and FASB Statement No. 33 , which called for the disclosure of the estimated replacement cost of physical assets in $10 \mathrm{~K}$ reports. ASR 190/FASB No. 33 was rescinded in part because financial analysts and investors were not using current cost data. For example, an Arthur Young \& Co. survey (reported in The CPA Journal, September 1983) revealed that most analysts believed that current cost estimates do not convey any new information. Consistent with this position, Ro (1981) found that the replacement cost disclosures did not affect the weekly transactions volume of common stock.

${ }^{8}$ Some appraisers also use the buyers' forecasted IRR for properties they have appraised in the past as the discount rate and apply this rate to a (5-10)-year forecast of cash flows from the property.
} 
informed investor will not pay more for a property than what other investors have recently paid for property similar with respect to location, age, size, scale, and quality of construction. Adjustments are made by the appraiser for deviations between the attributes of the property being appraised and characteristics of the comparable properties with adjustments made relative to the property being valued. A negative (positive) adjustment to the price of a comparable property is made if that comparable property possesses a positive (negative) feature (i.e., a newer building or more floors relative to the subject property).

Consequently, the existence of comparable properties is important regardless of which approach is employed in the valuation process. The value of the appraiser is that he not only determines which properties are comparable to the property(ies) being appraised based on his experience, but he also has access to information on the sale of comparable properties, including their price, financing terms, cash flows, and property attributes, which may or may not be a matter of public record or might not be made available in a timely manner as comparable sales occur. The appraiser also possesses information about the regional economies in which the properties are located, which is indirectly factored into the valuation process.

\section{The Informational Content of Appraisals}

Appraiser's Estimate of Value versus Stock Analyst's Valuation of Firm

There are some similarities in the functions performed by real estate appraisers and by brokerage analysts who follow stocks. Both bring an element of private information into the valuation process and use comparable firms in estimating the value of the firms. Analyst recommendations and appraisers' estimate of value both carry some weight as third-party estimates of firm value for investors and are likely to affect prices. However, some key differences exist between the appraisers' estimate of value and the stock analysts' recommendations on stock prices. First, analysts' estimates and valuations are generally made at the analysts' discretion, while real estate reappraisals are made at the discretion of the REIT being revalued. Consequently, there is likely to be a timing bias inherent in the latter, since firms that view themselves as undervalued are more likely to choose to have themselves reappraised than overvalued firms. Second, in contrast to analysts who are not handpicked or employed by the firms that they analyze, real estate appraisers are picked and remunerated by the REIT that they are 
revaluing. ${ }^{9}$ Here again, the potential for bias through choosing appraisers who are more likely to provide favorable recommendations cannot be ruled out. However, all properties in a REIT or RECO are reappraised at the same time, which minimizes the potential for further selection bias. ${ }^{10}$ These biases have to be weighed against the fact that the appraisers are provided with information about the properties that outsiders do not have. While analysts through their contacts or private research may unearth private information about the firm, real estate appraisers have a significant advantage since the firm not only supplies them with proprietary information on the properties being revalued, but they also bring with them proprietary information that other firms that they have valued have provided them in estimating the value of the properties and forecasting future market conditions. These differences have a couple of implications. The first is that REIT appraisals convey more private information than analyst recommendations. The second is that the discretionary nature of the reappraisal process makes favorable recommendations more likely than unfavorable ones. While this bias toward positive recommendations exists among stock analysts as well, the selection process for real estate appraisers accentuates the bias.

\section{The Appraisal Audit Process}

Since the decision to hire an outside, independent appraiser is discretionary as well as costly, questions that naturally arise are who decides on the appraisal audit and what is its economic justification. Interviews with the administrators of several REITs who do report appraised values in their financial reports reveal that the advisor to the trust, who administers the day-to-day operations of the trust, initially recommends to the board of directors or board of trustees (depending on whether a REIT is structured as a corporation or as a business trust, respectively) that the real estate of the REIT should be appraised and reported in the quarterly or annual report. Next, the board votes on the recommendation for an appraisal audit. In-house appraisals are performed for all properties in the REIT portfolio with all properties appraised at the same lime given board approval. An outside, independent $\mathrm{MAI}^{11}$ appraisal company is hired to verify the accuracy of the in-house estimate of the aggregate property value for the REIT portfolio. If the management's estimate of value is within 10 percent of the

\footnotetext{
${ }^{9}$ While analysts have some independence, the 6rms that they analyze still exercise considerable power. Analysts are reluctant to conclude that they are overvalued, since they are likely to lose future access to firms.

${ }^{10}$ We thank a reviewer for pointing out that another selection bias will exist if all properties in a REIT are not reappraised at the same time and that this bias will be more severe the greater the diversity of the REIT portfolio if insiders in all REITs are well informed.

${ }^{11} \mathrm{MAl}$ is an acronym for Member of the Appraisal Institute. To achieve this designation, an appraiser must meet certain educational requirements and have a number of years of practical experience.
} 
outside appraiser's value estimate, then the outside MAI appraiser issues a letter certifying the management's estimate of value. Otherwise, management must change their estimate of portfolio value to within 10 percent of the MAl's estimate of value in order to receive the valuation letter. Consequently, the appraisal process for REIT valuations is analogous to an independent accountant rendering his opinion on the financial condition of the firm after examining the books prepared by internal accountants of the firm. However, all REIT administrators interviewed stressed that the appraisal audit is not comparable to an accounting audit in the sense that the Securities and Exchange Commission (SEC) requires the latter but not the former to be undertaken for each firm. In addition to this, the FASB has strict GAAP guidelines for accounting audits, whereas no FASB guidelines exist on appraisal audits; it is strictly voluntary and in accordance with MAI principles and practices. After the MAl certification of value is rendered, board members of the firm receive information on the aggregate value of the property portfolio including both the in-house and MAI value estimates. According to REIT administrators interviewed, although board members can request in-house appraisals prior to receiving the outside, MAI appraisal, the standard procedure is to submit both sets of value estimates or only the MAI value estimate to board members once the outside, MAI appraisal is completed. Finally, the MAI aggregate estimate of value is released to the public through either the quarterly or annual report. These steps are summarized in Figure 1.

Several reasons were cited as to why board members require appraisal audits. The foremost reason given is that the MAl estimate of value is the measure most investors and shareholders feel comfortable with since the belief is that an informationally efficient market does not exist for real estate. Reporting an MAI value estimate gives credibility to what the REIT properties are approximately worth. A related reason given is that the outside investment community places an emphasis on appraised values because historical cost is not a good indicator of equity. A few REIT administrators stated that not all of their board members were involved in real estate and as such they wanted to know from time to time what was the aggregate value of the REIT's property portfolio. Another reason given is that the appraised value is used as the point of departure in negotiations when individual properties are sold. Thus, an appraisal may signal an impending sale of a property. ${ }^{12}$ One REIT administrator indicated that the decision to report appraisal values arose in response to FASB Statement No. 33 and ASR 190, discussed in note 7, even though REITs were exempt from these regulations. None of the REIT administrators stated that the board of directors require appraisal audits to measure the performance

\footnotetext{
${ }^{12} \mathrm{~A}$ reviewer has pointed out that this suggests that the REIT is about to expose itself to the uncertainty of the market and, since it has to pay out 95 percent of that sales price once received, it raises the question of whether there are any price consequences.
} 
of management. In fact, they emphasized that REIT management is not compensated based on appraisal values.

Another question that arises is whether board members who decide on an appraisal audit usually, often, or never hold stock in the company? Interviews with the directors of investor relations for several REITs that have reappraisals performed and reported in their financial reports reveal that board members usually hold common stock in the company. However, the investor relation directors pointed out that all board members are free to purchase stock only during the open purchase period because of the SEC rule that there exists a certain period before and after board meetings and company press releases where insiders are not allowed to purchase stock in the company. ${ }^{13}$

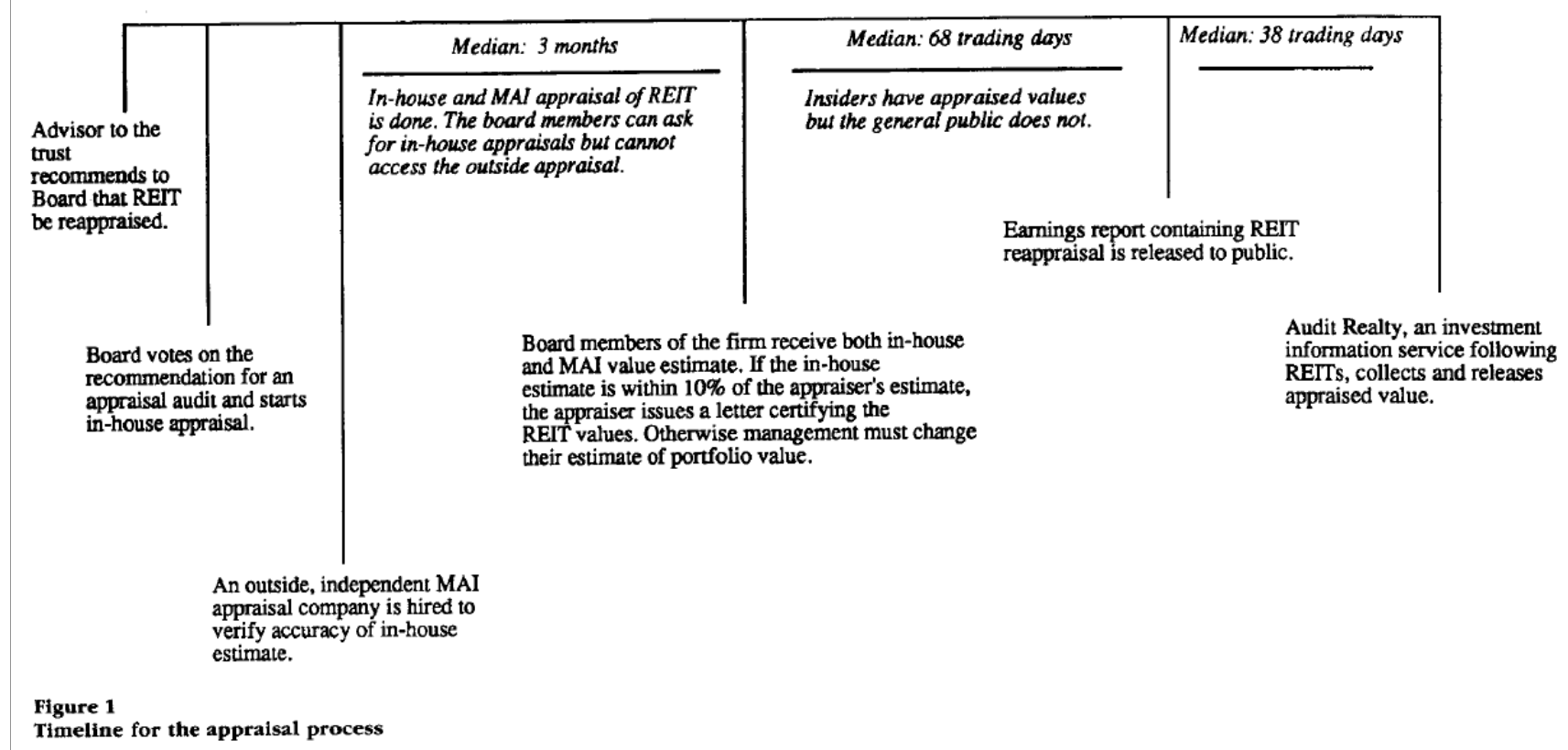

\section{Why Appraisals have Informational Value}

Are appraisals informationally valuable? That appraisals contain important information for investors is revealed in a survey by Coopers \& Lybrand of real estate analysts presented to the FASB in January 1983. This survey found that all analysts regarded current value disclosures as relevant with respect to the real estate industry. Moreover, 76 percent of the analysts felt that FASB should require the disclosure of the current appraised value of all real estate on a fully diluted per share basis,

\footnotetext{
${ }^{13}$ Since board members who decide on an appraisal audit usually hold stock in the company, this might represent another motive for hiring an appraiser (e.g., when they decide to hire an appraiser, they are deciding to obtain a greater amount of private information). We thank an anonymous reviewer for pointing out this fact.
} 
associating an independent auditor and/or appraiser with the disclosure for publicly held companies that own income-producing real estate.

Are insiders not as fully informed about the value of their properties as appraisers since insiders are the ones who initiate the reappraisal process? Whether insiders possess as much information on the value of their properties as appraisers depends in part on whether information on sales price and financing on real estate in each locale is publicly available, and how diversified their property portfolio is with respect to location. A survey done for the Appraisal Institute, the governing body for appraisers, in April 1990 and reprinted in Table 1 reveals that complete information on sales price and financing terms on commercial and residential real estate is a matter of public record in only five states-Arizona, Colorado, Connecticut, Minnesota, and Washington. In these states, buyers and/or sellers are required to sign an affidavit on the true price of the property. For all other states, either prices are not publicly available (16 states or 31 percent of the states), or if they are, no information on financing terms is available (36 states or 71 percent of the states). Even where prices are publicly available, some noise in prices might exist because of the manner of public disclosure. Price is disclosed in the public records either by the participants to the transaction signing an affidavit, purchasing conveyance stamps that reflect the total sales price or the downpayment, or reporting the sales price in the deed. Of the 35 states in which sales prices are a matter of public record, only 13 states require participants to sign affidavits as to the transaction price. The majority of states (18) merely require that either the buyer or seller purchase conveyance stamps where each stamp represents a fraction of the property's value. While the value can, in theory, be imputed from transfer stamps, there are some instances, especially with foreign acquisitions of commercial properties, where purchasers buy more than the required amount of transfer stamps to hide the true transaction price. Furthermore, the price in the public record is not broken down into what part of the price is attributable to real estate and what portion represents personal property. In four states, the price of the property is reflected in the deed. In contrast to pricing information, only 15 states disclose financing information either through an affidavit or a deed in general. The extent of this financing information varies with each state, with some states requiring disclosure of only the loan amount but not the loan terms. No state currently requires that cash flow information be a matter of public record, although New York requires that property owners must report this information to the tax assessor who keeps the information confidential. In an attempt to reflect the availability of real estate sales and financing information in public records, the current study uses an arbitrary scoring process to reflect the transaction information $(\tau)$ available in each state $i$, where $\tau$, is between zero and unity $\left(0<\tau_{i}<1\right)$. A score of zero is given to a state if no price of mortgage information 
is publicly available. If only mortgage information but not transaction price is a matter of public record, then a score of .25 is assigned to a state. On the other hand, if information on transaction prices but not mortgage financing is publicly available, then that state is given a .40. This score of .40 is increased to .50 if state regulations require the buyer and/ or the seller to sign an affidavit verifying the transaction price. A state receives a score of .65 if both the transaction price and mortgage terms are accessible, while a perfect score of 1.00 is assigned to a state if an affidavit verifying the transaction price is also required. The weights used in the arbitrary scoring process were based on discussions with appraisers at the New York office of Cushman \& Wakefield, as well as the 15 years of experience of the second author as a real estate broker and consultant.

In Table 2, we report aggregate information on property characteristics for REITs and RECOs to give the reader some idea of the extent to which insiders of the firm can obtain publicly available information on transaction prices and mortgage terms for competing properties in their local real estate market as well as where most of the properties in REIT and RECO portfolios are located. In this table, it is revealed that price information is not publicly available for 27 percent and 19 percent of the properties for the REIT and RECO portfolios, respectively, in the aggregate. Some noise also exists in the price data for 77 percent of the REIT and RECO properties since no affidavit is required. In addition to this, no financing information is publicly available for 79 percent and 70 percent of the properties in the REIT and RECO portfolios, respectively, in the aggregate. In summary, information on prices and mortgage terms for most local real estate markets that REITs and RECOs invest in is not comprehensive in general. Table 2 also shows that a typical REIT portfolio consists of properties in 17 cities, 7 states, and 4 regions, with the number of cities varying from 3 to 35, the number of states varying from 1 to 17, and the number of regions varying from 1 to 8 . Based on our arbitrary information score, information on transactions involving properties comparable to that in each REIT portfolio is publicly available for only 43.3 percent of a REIT portfolio on average. This percentage varies from 2.4 percent for Weingarten Realty, which has most of its properties located in Houston, Texas, to 72.1 percent for Mony Real Estate. This aggregate percentage of public information available on the underlying real estate in the portfolio is computed as the sum of the products of the percentage (\%) of the property portfolio located in state $i$ $\left(w_{i}\right)$ multiplied by the percentage $(\%)$ of information on real estate prices and financing terms that is publicly available in state $i(r$,$) . Mathematically,$ Agg. \% of publicly available information on properties in portfolio $=\sum_{i=1}^{N} w_{i} \tau_{i}$. In terms of the percentage of properties by location, only 22 percent of the properties in a REIT portfolio are located in any one city. However, a higher concentration of properties exists with respect to the 
maximum number of properties located in one state (48 percent) or one region (59 percent) in general.

This suggests that REITs tend to diversify across cities to a greater extent than across states and regions.

A similar situation exists with respect to real estate companies.

Table 1

Appraisal Institute Survey (April 1990): The availability of real estate sales and financing

information in public records-Disclosures on commercial and residential sales

\begin{tabular}{|c|c|c|c|c|c|c|c|c|c|c|}
\hline \multirow[b]{2}{*}{ State } & \multirow[b]{2}{*}{$\begin{array}{l}\text { Score } \\
(\phi,)\end{array}$} & \multirow{2}{*}{$\begin{array}{c}\begin{array}{c}\text { Dis- } \\
\text { closes }\end{array} \\
\text { sales } \\
\text { price }\end{array}$} & \multicolumn{4}{|c|}{$\begin{array}{l}\text { How price is disclosed in } \\
\text { public records }\end{array}$} & \multirow{2}{*}{$\begin{array}{c}\text { Dis- } \\
\text { closes } \\
\text { financ- } \\
\text { ing }\end{array}$} & \multicolumn{3}{|c|}{$\begin{array}{l}\text { How financing is } \\
\text { disclosed }\end{array}$} \\
\hline & & & $\begin{array}{l}\text { Afti- } \\
\text { davit }\end{array}$ & TStamps' E & EStamps $^{2}$ & Deed & & $\begin{array}{l}\text { Affi- } \\
\text { davit }\end{array}$ & Deed & Other' \\
\hline Alabama & .00 & No & No & No & No & No & No & No & No & No \\
\hline Alaska & .00 & No & No & No & No & No & No & No & No & No \\
\hline Arizona & 1.00 & Yes & Yes & No & No & No & Yes & Yes & No & No \\
\hline Arkansas & 40 & Yes & No & Yes & No & No & No & No & No & No \\
\hline California & .40 & Yes & No & No & Yes & No & No & No & No & No \\
\hline Colorado & 1.00 & Yes & Yes & No & No & No & Yes & Yes & No & No \\
\hline Connecticut & 1.00 & Yes & Yes & No & No & No & Yes & No & Yes & No \\
\hline Delaware & .50 & Yes & Yes & No & No & No & No & No & No & No \\
\hline Florida & .65 & Yes & No & Yes & No & No & Yes & Yes & No & No \\
\hline Georgia & .40 & Yes & No & Yes & No & No & No & No & No & No \\
\hline Hawaii & .40 & Yes & No & Yes & No & No & No & No & No & No \\
\hline Idaho & .00 & No & No & No & No & No & No & No & No & No \\
\hline Illinois & .50 & Yes & Yes & No & No & No & No & No & No & No \\
\hline Indiana & .00 & No & No & No & No & No & No & No & No & No \\
\hline lowa & .65 & Yes & No & Yes & No & No & Yes & No & Yes & No \\
\hline Kansas & .00 & No & No & No & No & No & No & No & No & No \\
\hline Kentucky & .40 & Yes & No & No & No & Yes & No & No & No & No \\
\hline Louisiana & .00 & No & No & No & No & No & No & No & No & No \\
\hline Maine & .50 & Yes & Yes & No & No & No & No & No & No & No \\
\hline Maryland & .50 & Yes & Yes & No & No & No & No & No & No & No \\
\hline Massachusetts & .65 & Yes & No & Yes & No & No & Yes & No & Yes & No \\
\hline Michigan & .00 & No & No & No & No & No & No & No & No & No \\
\hline Minnesota & 1.00 & Yes & Yes & No & No & No & Yes & Yes & No & No \\
\hline Mississippi & .00 & No & No & No & No & No & No & No & No & No \\
\hline Missouri & .25 & No & No & No & No & No & Yes & No & Yes & No \\
\hline Montana & .00 & No & No & No & No & No & No & No & No & No \\
\hline Nebraska & .40 & Yes & No & Yes & No & No & No & No & No & No \\
\hline Nevada & .50 & Yes & Yes & No & No & No & No & No & No & No \\
\hline New Hampshire & .40 & Yes & No & Yes & No & No & No & No & No & No \\
\hline New Jersey & 40 & Yes & No & No & No & Yes & No & No & No & No \\
\hline New Mexico & .00 & No & No & No & No & No & No & No & No & No \\
\hline New York & .65 & Yes & No & Yes & No & No & Yes & No & Yes & No \\
\hline North Carolina & .65 & Yes & No & No & Yes & No & Yes & No & No & Yes \\
\hline North Dakota & .00 & No & No & No & No & No & No & No & No & No \\
\hline Ohio & .50 & Yes & Yes & No & No & No & No & No & No & No \\
\hline Oklahoma & .00 & No & No & No & No & No & No & No & No & No \\
\hline Oregon & .40 & Yes & No & No & No & Yes & No & No & No & No \\
\hline Pennsylvania & 40 & Yes & No & Yes & No & No & No & No & No & No \\
\hline Rhode Isiand & .40 & Yes & No & Yes & No & No & No & No & No & No \\
\hline South Carolina & .50 & Yes & Yes & No & No & No & No & No & No & No \\
\hline South Dakota & 40 & Yes & No & Yes & No & No & No & No & No & No \\
\hline Tennessee & .65 & Yes & No & No & No & Yes & Yes & No & Yes & No \\
\hline Texas & .00 & No & No & No & No & No & No & No & No & No \\
\hline Utah & .00 & No & No & No & No & No & No & No & No & No \\
\hline Vermont & .50 & Yes & Yes & No & No & No & No & No & No & No \\
\hline Virginia & .40 & Yes & No & No & Yes & No & No & No & No & No \\
\hline Washington & 1.00 & Yes & Yes & No & No & No & Yes & No & No & Yes \\
\hline West Virginia & .65 & Yes & No & No & Yes & No & Yes & No & Yes & No \\
\hline Wisconsin & .40 & Yes & No & Yes & No & No & No & No & No & No \\
\hline Wyoming & .25 & No & No & No & No & No & Yes & No & No & Yes \\
\hline $\begin{array}{l}\text { District of Colum } \\
\text { bia }\end{array}$ & .65 & Yes & No & Yes & No & No & Yes & No & Yes & No \\
\hline No. states-Yes & & 35 & 13 & 14 & 4 & 4 & 15 & 4 & 8 & 3 \\
\hline No. states-No & & 16 & 38 & 37 & 47 & 47 & 36 & 47 & 43 & 48 \\
\hline
\end{tabular}




\begin{tabular}{|c|c|c|c|c|c|c|c|c|c|c|}
\hline \multirow[b]{2}{*}{ State } & \multirow[b]{2}{*}{$\begin{array}{l}\text { Score } \\
\left(\phi_{l}\right)\end{array}$} & \multirow{2}{*}{$\begin{array}{l}\text { Dis- } \\
\text { closes } \\
\text { sales } \\
\text { price }\end{array}$} & \multicolumn{4}{|c|}{$\begin{array}{l}\text { How price is disciosed in } \\
\text { public records }\end{array}$} & \multirow{2}{*}{$\begin{array}{c}\text { Dis- } \\
\text { - closes } \\
\text { financ- } \\
\text { ing }\end{array}$} & \multicolumn{3}{|c|}{$\begin{array}{l}\text { How financing is } \\
\text { disclosed }\end{array}$} \\
\hline & & & $\begin{array}{l}\text { Aft: } \\
\text { davit }\end{array}$ & TStamps' & EStamps ${ }^{2}$ & Deed & & $\begin{array}{l}\text { Aff- } \\
\text { davit }\end{array}$ & Deed & Other $^{y}$ \\
\hline$\%$ states-Yes & & 69 & 25 & 27 & 8 & 8 & 29 & 8 & 16 & 6 \\
\hline$\%$ states - No & & 31 & 75 & 73 & 92 & 92 & 71 & 92 & 84 & 94 \\
\hline
\end{tabular}

Reprinted with permission of the Appraisal Institute. Where missing data existed, the Appraisal Institute president of the state chapter was called.

' Document fee for conveyance stamps are based on total consideration (price paid).

2 Document fee for conveyance stamps are based on equity consideration (down payment).

' Other responses: Maryland, on recorded mortgage; North Carolina, deed of trust; Washington, note with terms; Wyoming, bank option when fling "notice of mortgage."

In summary, most of the REITs and RECOs in our sample have properties in several locales with prices and financing terms not publicly available in all of these locales. In states where information is publicly available, insiders must constantly go to the public records in each city where the property is located to obtain this information, thus incurring a monitoring cost. ${ }^{14}$ Insiders must also verify the sales and financing information because of noise in the public records. The magnitude of this monitoring cost depends on how many properties are located in different real estate markets. Consequently, insiders also extract valuable information from appraisals because appraisers use private information that they possess on the value, financing, and cash flows of comparable properties. ${ }^{15}$ The point is that while insiders may have been motivated to have their firms reappraised because they believed them to be undervalued, the reappraisals may not confirm their initial beliefs and do provide them with new information about the true value of their firms. As a consequence, even insiders in the REIT can be wrong in their assessments of the REIT's real value and can obtain considerable new information about the REIT's true value from the appraisal. The distribution of the differences between appraisal value and the market price at the start of the month that the appraisal is completed provides support for this notion. Of the 77 appraisals that are included in our sample, 43 represent positive appraisals (with an appraisal value greater than the market price at the time the appraisal is completed), and 33 are negative appraisals (with an appraisal value less than the market price). In Figure 2, we provide a frequency distribution for the difference between appraisal value and the market price, divided by the market price. The distribution is clearly nonnormal and positively skewed.

The relationship between the informational value of real estate appraisals and the property composition of the appraised REITs is examined in Table 3, where we regress the square of the

\footnotetext{
${ }^{14}$ There are commercial data vendors that sell data on each transaction for certain states such as Real Estate Data, Inc. (REDI). However, these vendors do not attempt to verify the accuracy of public information.

${ }^{15}$ In states where information is not publicly available, appraisers typically trade information on price and financing terms but not cash flows among themselves. Appraisers also seek out sellers, buyers, and their agents to verify pricing and financing information on each transaction, regardless of whether this is public information.
} 
differences in logs [as suggested in Manski (1991)] between the appraised value and the market price at the time of the appraisal (to correct for the nonnormalities noted above in Figure 2) on a number of measures of property composition: the number of properties owned, the number of cities that the REIT operates in, the number of types of property owned, and the number of states and regions in which the REIT operates. ${ }^{16}$

In Table 3, we show that the absolute deviation between appraisal value and the market value at the time of the appraisal is related to the composition of the asset portfolio held by the REIT. More specifically, we are much more likely to observe large differences between appraised values and market values for REITs that operate in several states and regions. However, the number of properties and types of properties that a REIT owns are not significantly related to the informational value of the appraisal. One explanation for these findings is that insiders in REITs that have properties in a large number of states and regions find the proprietary information brought in by appraisers to be valuable in determining whether their firms are fairly valued since they are less likely to have a comparative information advantage on "localized" real estate market conditions. If the appraiser is right, this would suggest that the mispricing of REITs is directly related to the expense of aggregating regional information. An alternative explanation for this finding is that insiders and appraisers are equally well informed but their valuations of the properties are different (i.e., the findings in Table 3 just reflect heterogeneity in the information aggregation process). To test this, we regressed the square of the differences in logs between appraisal value and the market value after the appraisal had been completed and publicly revealed (in the earnings announcement) against measures of property composition and found no significant correlations with any of the measures. This suggests that the findings in Table 3 reflect more than information heterogeneity and at least partially reflect information brought in by the appraiser. Consequently, some support exists for the primary reason cited as to why board members require appraisal audits-namely, that the real estate market is informationally inefficient and therefore the MAl estimate of value is the measure most investors and shareholders feel comfortable with.

\footnotetext{
${ }^{16}$ There is a high correlation between some of these measures. Hence, we report multiple univariate regressions.
} 
Table 2

REITs and RECOs that report appraised value per share characteristics of real estate portfolios

\begin{tabular}{|c|c|c|c|c|c|c|c|c|c|c|c|c|}
\hline & & & & & \multicolumn{8}{|c|}{$\begin{array}{c}\text { No. (\%) of properties in aggregate for REIT's } \\
\text { and RECOs }\end{array}$} \\
\hline & & & & & \multicolumn{2}{|c|}{ REIT REIT\% } & \multicolumn{3}{|c|}{ RECO RECO $\%$} & \multirow{2}{*}{$\begin{array}{r}\text { Total } \\
417\end{array}$} & \multicolumn{2}{|c|}{ Total\% } \\
\hline \multirow{4}{*}{\multicolumn{5}{|c|}{$\begin{array}{l}\text { No price information is publicly available } \\
\text { No affidavit on price is publicly available } \\
\text { No financing information is publicly available } \\
\text { No information on cash flow is publicly available }\end{array}$}} & 245 & 27.47 & \multicolumn{2}{|c|}{172} & 19.42 & & \multicolumn{2}{|c|}{23.46} \\
\hline & & & & & \multirow{2}{*}{$\begin{array}{l}691 \\
699\end{array}$} & 77.63 & 682 & & 77.24 & 1373 & \\
\hline & & & & & & 78.53 & 620 & & 70.23 & 1319 & \multicolumn{2}{|c|}{$\begin{array}{l}77.43 \\
74.40\end{array}$} \\
\hline & & & & & 890 & 100.00 & \multicolumn{2}{|c|}{883} & 00.00 & 1773 & \multicolumn{2}{|c|}{100.00} \\
\hline & \multicolumn{12}{|c|}{ Average no. and maximum $\%$ of real estate in any one category } \\
\hline & \multicolumn{6}{|c|}{ REITs' } & \multicolumn{6}{|c|}{$\mathrm{RECOS}^{2}$} \\
\hline & \multicolumn{3}{|c|}{ No. } & \multicolumn{3}{|c|}{$\%$ invested in } & \multicolumn{3}{|c|}{ No. } & \multicolumn{3}{|c|}{$\%$ invested in } \\
\hline & Avg. & Min. & Max. & Avg. & Min. & Max. A & Avg. & Min. & Max. & Avg. N & Min. & Max. \\
\hline No. of properties & 30 & 3 & 149 & & & & 42 & 1 & 142 & & & \\
\hline $\begin{array}{l}\text { No. of property types invested } \\
\text { in/maximum } \% \text { of real estate } \\
\text { in any one property type }\end{array}$ & 4 & 1 & 6 & 63 & 31 & 100 & 3 & 1 & 7 & 66 & 8 & 100 \\
\hline $\begin{array}{l}\text { No. of cities invested in/ } \\
\text { maximum \% of real estate } \\
\text { in any one city }\end{array}$ & 17 & 3 & 44 & 22 & 6 & 67 & 21 & 1 & 68 & 33 & 3 & 100 \\
\hline $\begin{array}{l}\text { No. of states invested in/ } \\
\text { maximum } \% \text { of real estate } \\
\text { in any one state }\end{array}$ & 7 & 1 & 17 & 48 & 15 & 100 & 9 & 1 & 23 & 49 & 15 & 100 \\
\hline $\begin{array}{l}\text { No. of regions invested in/ } \\
\text { maximum } \% \text { of real estate } \\
\text { in any one region }\end{array}$ & 4 & 1 & 9 & 59 & 23 & 100 & 4 & 1 & 9 & 58 & 17 & 100 \\
\hline $\begin{array}{l}\% \text { of real estate market } \\
\text { information that is } \\
\text { publicly available }\end{array}$ & & & & 43 & 2 & 72 & & & & 49 & 27 & 71 \\
\hline
\end{tabular}

REITs include BankAmerica Realty/BRE, Burnham Pacific, California REIT, Copley Properties. Duke Realty, EQK Realty Investment I, Federal Realty, First Union, Hotel Investor, Hotel Properties, HRE Properties, IRT, Mony Real Estate Inv, Mortgage Growth (MGI), MSA Realty, New Plan Realty, Pacific Realty Trust, Pennsylvania REIT, Property Capital, Prudential Realty Capital, Rampac, REIT of America, Real Estate Investment Properties, San Francisco Real Estate, Santa Anita, Sierra Capital Realty IV and VI, Trammel Crow REIT, Washington REIT, Weingarten Realty, Wells Fargo Mortgage \& Equity, and Western Investment REIT.

RECOs include Bay Financial, Benequity Holdings, Centennial Group, EQK Green Acres, Equitable Real Estate SC, Fairfield Communities, lorest City A and B, Koger Company, La Quinta Motor Inns L.P, National Realry, Newhall Investment Properties, Newhall Land, Perini Investment Properties, Prime Motor Inn LP, Red Lions Inns, Saul (B.F.) REIT, Shopco Laurel Center, Transamerica Realty, Unicorp America, and United National.

'This figure represents the aggregate percentage of public information available on the underlying real estate in the portfolio. This percentage is computed as the sum of the products of the percent of the property portfolio in state $i(w)$ multiplied by the percent of information on real estate prices and financing terms that is publicly available in state $i\left(\tau_{i}\right)$. An arbitrary scoring process is used to reflect the transactions information $(\tau)$ in each state $i$, where $\tau$, is between zero and unity. Mathematically,

Aggregate \% of publicly available information on underlying real estate in portfolio

$$
=\sum_{i=1}^{\infty} w_{r} \tau_{r} .
$$




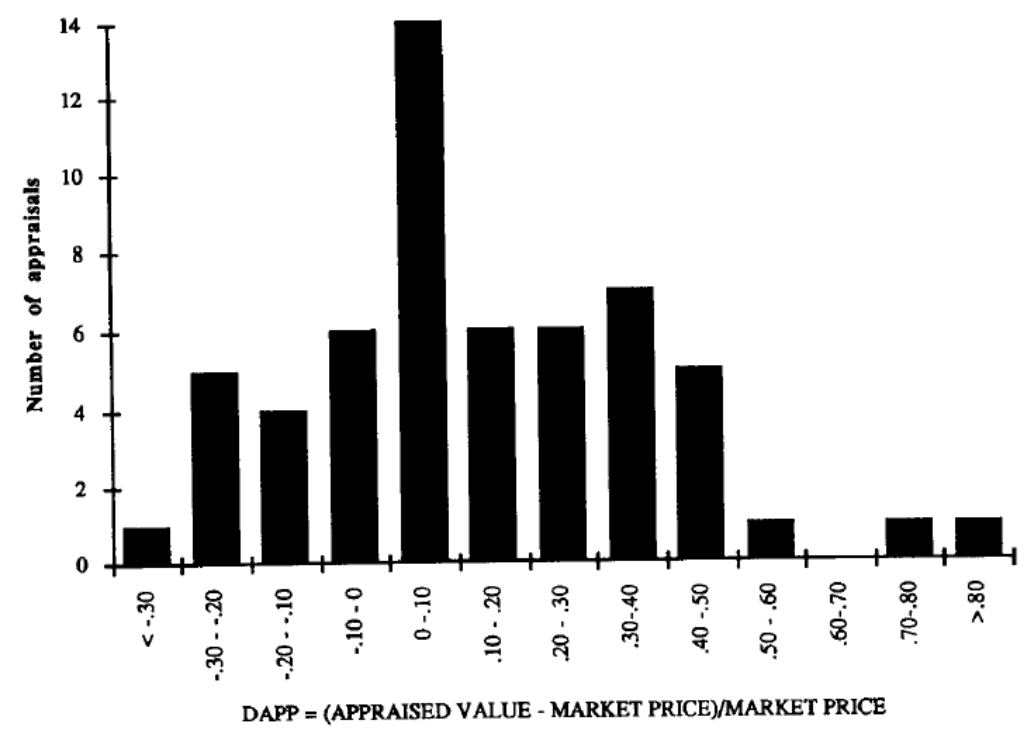

Figure 2

Difference between appraised value and market price at time of appraisal frequency distribution

distribution
The sample includes all REIT reappraisals made between 1982 and 1989 for which market price The sample includes all REIT reappraisals made between 1982 and 1989 for which market price and the market price, divided by the market price, is calculated at the time of the appraisal.

Table 3

Appraised values, market values, and RErT property composition

\begin{tabular}{|c|c|c|c|c|c|c|}
\hline SDAPP & $=$ & $\begin{array}{l}0.1616^{*} \\
(2.987)\end{array}$ & - & $\begin{array}{l}0.0016 \text { PPTYS } \\
(-1.121)\end{array}$ & $F=1.257$ & $R^{2}=0.0205$ \\
\hline SDAPP & $=$ & $\begin{array}{l}0.1815^{*} \\
(2.569)\end{array}$ & + & $\begin{array}{l}0.0040 \text { CITIES } \\
(1.072)\end{array}$ & $F=1.150$ & $R^{2}=0.0188$ \\
\hline SDAPP & $=$ & $\begin{array}{l}0.1127 \\
(1.778)\end{array}$ & - & $\begin{array}{l}0.00207 y p e s \\
(-0.400)\end{array}$ & $F=0.660$ & $R^{2}=0.0160$ \\
\hline SDAPP & $=$ & $\begin{array}{l}0.1127 \\
(1.778)\end{array}$ & + & $\begin{array}{l}0.0156 * * \text { States } \\
(2.16)\end{array}$ & $F=4.856^{* *}$ & $R^{2}=0.0798$ \\
\hline SDAPP & $=$ & $\begin{array}{l}0.1092 \\
(1.487)\end{array}$ & + & $\begin{array}{l}0.0385^{* *} \text { Regions } \\
(2.22)\end{array}$ & $F=5.130^{* *}$ & $R^{2}=0.0843$ \\
\hline
\end{tabular}

$t$-statistics are reported in brackets under the coefficients. SDAPP: Square of the differences in logs of appraised and market values. SDAPP, ( $\log$ (appraised value) - $\log$ (market value)) ${ }^{2}$; PPTYS, number of properties owned by the REIT at the time of the appraisal; Cities, number of cities in which the REIT owned properties at the time of the appraisal; Types, number of types of properties owned by the REIT at the time of the appraisal; States, number of states in which properties are owned by the REIT at the time of the appraisal; Regions, number of regions in which properties are owned by the REIT at the time of the appraisal.

* Significant at the .01 level.

* Significant at the .05 level.

\section{REITs with Appraisals versus REITs without Appraisals}

The fact that REITs and RECOs choose whether and when they are appraised and who appraises them exposes us to a potent problem of selection bias. We would expect to observe insiders in firms that view themselves as undervalued to be more likely to choose to have their properties reappraised than insiders in firms that view themselves as overvalued. Furthermore, they are likely to choose 
appraisers who will give them favorable appraisals. This bias toward positive appraisals is visible in Figure 2.

To examine the extent of this selection bias, we first examine the differences between real estate firms that chose to have appraisals during the period of our sample and real estate firms that did not have any reappraisals during the period. The control sample of non-appraised firms was created from the COMPUSTAT file and includes all REITs and real estate corporations that were listed between 1982 and 1989 and did not have any reappraisals during the period. Using the quarterly COMPUSTAT tape, we obtain data on four sets of variables: (1) size, as measured by the book value of total assets and the market value of equity; (2) value measures, estimated using price-earnings ratios, price-book value $(\mathrm{P} / \mathrm{BV})$ ratio, and price-cashflow (P/CF) ratios; ${ }^{17}(3)$ leverage measures, evaluated through debt-equity ratios; and (4) volume measures, as captured in average quarterly trading volume. The data were obtained for appraised firms only for the years in which they were appraised and for non-appraised firms for every year from 1982 to 1989- The cross-sectional average values for each measure were obtained for each year from 1982 to 1989 for non-appraised firms and compared to the corresponding cross-sectional averages for appraised firms in that year. In addition, the cumulated annual return in the 250 trading days prior to each reappraisal is estimated for the appraised firm and for the portfolio of non-appraised firms in the control sample. The cross-sectional averages and standard errors for each of these measures is reported for appraised and non-appraised real estate firms in Table 4.

The statistical significance of the differences between the two subsamples is captured in two statistics that are also reported in Table 4: a parametric t-statistic, which tests for significant differences between the subsample means, and a $\chi^{2}$ statistic from a Wilcoxon rank-sum test. There is evidence here that appraised REITs are not significantly different from non-appraised REITs in size, trading volume, or leverage, but are likely to have lower price-earnings and price-book value ratios. To the extent that one accepts the notion that insiders in firms that have lower price-earnings and price-book value ratios are more likely to view themselves as undervalued, this adds to our concern of a selection bias. There seems to be little in preappraisal returns to differentiate between the two subgroups, with the appraised REITs having slightly higher returns in the preappraisal period. This is illustrated further in Figure 3 , where the cumulated abnormal returns for the appraised and non-appraised REITs are shown for the 250 trading days prior to completion of an appraisal.

\footnotetext{
${ }^{17}$ There is evidence in the literature that portfolios with low $\mathrm{P} / \mathrm{E}$ ratios, low $\mathrm{P} / \mathrm{BV}$ ratios, and low $\mathrm{P} / \mathrm{CF}$ ratios earn abnormal returns. It is unclear whether this is the result of mismeasurement of risk or a reflection that stocks in these portfolios are more likely to be undervalued. Practitioners (such as analysts) continue to use these variables as proxies for value.
} 
We will examine statistical approaches that take into account the selection bias inherent in this process later in the next section.

\section{Sample and Methodology}

Sample Description

Our sample includes 34 REITs and 20 RECOs that fit the following criteria.

- They were traded on either the New York or American Stock exchanges between 1982 and 1989 and have information available for the period on the CRSP daily returns database.

- They have information available on quarterly earnings announcement dates and earnings per share on the COMPUSTAT quarterly database for the time period that they are listed on the CRSP tape.

- They have at least one real estate reappraisal during the time period. The reappraisal data was obtained from the Realty Stock Review published by Audit Investments, and included the month in which the appraisal was completed and the appraised value. The date of the earnings announcement containing the appraisal value was obtained from the Wall Street Journal. In addition, the date on which this information was reported by Audit Investments, an information service that summarizes and reports on appraisal values to its subscribers, was also obtained.

- To mitigate the issue of survivor bias, the sample also includes firms that were listed for only a portion of the period between 1982 and 1989 and were subsequently delisted for any reason. 
Table 4

Appraised REITs versus nonappraised REITs: Firm characteristics

\begin{tabular}{|c|c|c|c|c|c|c|c|c|}
\hline \multirow[b]{2}{*}{ Firm characteristic' } & \multicolumn{3}{|c|}{ Appraised firms } & \multicolumn{3}{|c|}{ Nonappraised firms } & \multicolumn{2}{|c|}{ Differences } \\
\hline & Mean & SE & Median & Mean & $\mathrm{SE}$ & Median & $t$-statistic ${ }^{2}$ & $x^{2 *}$ \\
\hline \multicolumn{9}{|l|}{ Size variables } \\
\hline Total assets & 168.36 & 23.78 & 105.13 & 181.85 & 17.99 & 147.84 & 0.45 & 2.72 \\
\hline \multicolumn{9}{|l|}{ Trading volume } \\
\hline Quarterly trading volume & 0.8066 & 0.1336 & 0.423 & 0.7104 & 0.0725 & 0.718 & -0.63 & 1.10 \\
\hline \multicolumn{9}{|l|}{ Value measures } \\
\hline P/E ratio & 60.36 & 8.01 & 44.45 & 159.01 & 27.04 & 95.31 & $3.50^{*}$ & $19.98^{*}$ \\
\hline $\mathrm{P} / \mathrm{CF}$ ratio & 57.94 & 7.88 & 44.02 & 122.95 & 20.41 & 77.92 & $2.97^{*}$ & $16.87^{\bullet}$ \\
\hline $\mathrm{P} / \mathrm{BV}$ ratio & 1.2963 & 0.1763 & 1.0379 & 2.6954 & 0.3999 & 1.2322 & $2.71^{*}$ & $6.47^{*}$ \\
\hline \multicolumn{9}{|l|}{ Debt measures } \\
\hline $\mathrm{D} / \mathrm{E}$ ratio & 0.5272 & 0.1143 & 0.3461 & 2.4266 & 1.2334 & 0.3164 & 1.53 & 0.05 \\
\hline \multicolumn{9}{|l|}{ Preappraisal returns } \\
\hline Days: -250 to -200 & $7.10 \%$ & $1.60 \%$ & $5.04 \%$ & $7.22 \%$ & $0.86 \%$ & $7.04 \%$ & -0.04 & -0.10 \\
\hline Days: -200 to -150 & $6.19 \%$ & $1.28 \%$ & $4.52 \%$ & $5.11 \%$ & $0.90 \%$ & $2.83 \%$ & 0.75 & 1.27 \\
\hline Days: -150 to -100 & $3.85 \%$ & $0.96 \%$ & $4.30 \%$ & $3.44 \%$ & $0.57 \%$ & $2.29 \%$ & 0.24 & 0.48 \\
\hline Days: -100 to -50 & $1.94 \%$ & $1.09 \%$ & $3.49 \%$ & $2.01 \%$ & $0.63 \%$ & $3.19 \%$ & -0.02 & -0.07 \\
\hline Days: -50 to 0 & $1.05 \%$ & $1.02 \%$ & $0.48 \%$ & $0.31 \%$ & $0.71 \%$ & $0.06 \%$ & 0.66 & 0.85 \\
\hline
\end{tabular}

The holdout sample of nonappraised REIT firms includes all firms that did not have appraisals during the $1982-1989$ period. The data for size, trading, and value and debt measures are obtained for each year from 1982 to 1989 for this group and matched up to the corresponding values for the appraised firm group in that year. The returns are estimated for a portfolio of nonappraised firms for the 250 trading days prior to each firm's appraisal.

- The data for the size, value, and debt measures was obtained from the quarterly COMPUSTAT tape, while the preappraisal returns were obtained from the CRSP tape from 1982-1989. The cross-sectional means and standard errors are reported.

2 This $t$-statistic is a parametric test of whether the means of the two groups are significantly different.

"The $\chi^{2}$-statistic, with one degree of freedom, is from a Wilcoxon rank sum test.

- Significant at the $1 \%$ level.

Notes 1 and 2 in Table 2 list the REITs and real estate companies in our sample, respectively.

These firms had a total of 77 earnings reports with appraisal values in them and 357 other earnings reports during this time period. 


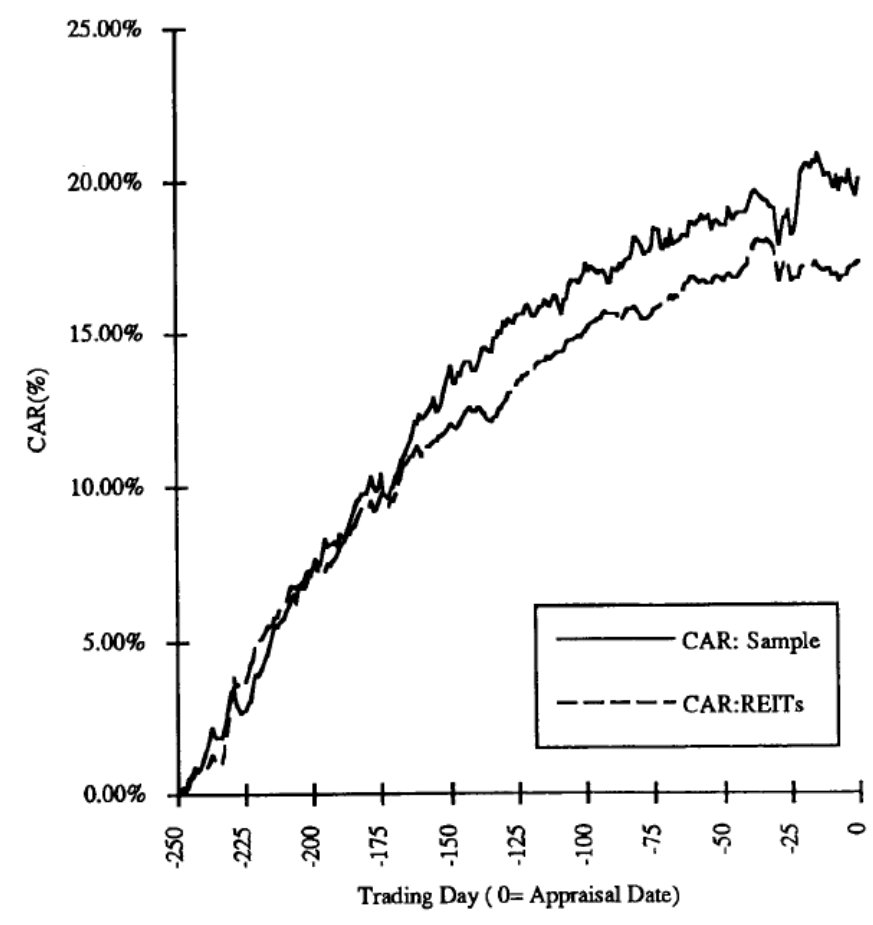

Figure 3

Cumulated abnormal returns prior to appraisal: appraised REITs versus nonappraised REITs

The sample of appraised REITs includes all REITs that had appraisals between 1982 and 1989. The control sample of nonappraised REITs includes all REITs that did not have any appraisals between 1982 and 1989 . The cumulated abnormal return is calculated relative to the market model parameters estimated from days -370 to -251 , where day 0 is the appraisal date for appraised firms. The return on the nonappraised REIT portfolio is estimated for the same 250 days prior to each appraisal date in our sample, and the average cumulated returns are reported for days -250 to 0 .

\section{The Sequence of Information Revelation and Testable Hypotheses}

Substantial evidence exists that there is insider trading around corporate announcements [John and Lang (1991), Copeland and Lee (1988), and Hirschey and Zaima (1989)] and that this insider trading is motivated by private information. ${ }^{18}$ In modeling this relationship, the following sequence of actions is usually assumed. First, private information about the firm's true value is revealed to insiders in the firm. Second, insiders use this information to trade on their own account and in the process reveal some or all of the information to other traders [which is the signaling feature modeled by John and Mishra (1990)]. This information is next revealed to the general public and the magnitude of the market reaction is determined both by the attributes of the information and by the signaling effects of insider trading preceding the public announcement. Finally, this information is repackaged and analyzed by secondary sources and then reported to the public.

\footnotetext{
${ }^{18}$ Keown and Pinkerton (1981) also report substantial insider trading beginning one month before the announcement of corporate takeovers, and find that one half of the price reaction takes place before the announcement. In contrast, Jarrell and Poulsen (1989) find no evidence that the pre-bid run-up is greater for firms that have been identified in government insider trading allegations than for other target firms in their sample.
} 
Empirical researchers can generally observe the date of the public announcement with ease but are unable to identify when private information is revealed to insiders in the firm as well as the content of this information. Consequently, event studies have focused on market reactions to public announcements (of earnings, dividends, stock splits, etc.) but have not examined the effects that insider trading preceding these reports may have on their findings. Even those studies that have attempted to consider insider trading [Keown and Pinkerton (1981), Hirschey and Zaima (1989)] have focused their attention on public announcements and examined the period preceding these announcements for evidence of insider trading and abnormal price reaction.

The unique feature of our dataset is that we can observe when private information is revealed to insiders and the content of the private information release as well as the public and secondary announcements of this information. Consequently, we have the opportunity to examine several hypotheses associated with each stage in the information revelation process. Once the decision to appraise, described in detail in the prior section, has been made, the information stages and the corresponding hypotheses are as follows.

Information stage 1: Arrival of private information to public announcement. Insider holdings are posited to increase (decrease) in response to "good (bad) news" private information, which in turn should elicit a positive (negative) price response. Moreover, the magnitude of this price response is hypothesized to increase in intensity the larger the change in the level of insider holdings, which in turn is a function of the spread between the appraisal value and the market price at the time of the appraisal.

Information stage 2: Public announcement of private information. No market reaction to the public announcement of private information is expected to obtain if changes in the level of insider holdings act as a signal of private information. However, a market reaction is likely if insiders are successful in camouflaging their trades. The extent to which insiders are able to conceal inside information depends in part on the time length of information stage 1.

Information stage 3: Secondary release of information by analysts. Advisory services' reports, which analyze and repackage public information, are not hypothesized to act as a secondary signal to influence market prices unless residual information exists that the insider trading and the public announcement do not convey or unless the way that secondary sources process public information offers new insights to investors since these analysts concentrate on a given industry. 


\section{Methodology}

There are three time periods upon which we focus our attention - the month in which the appraisal is made, the days around the earnings announcement containing the appraisal value, and the time period around the Audit Research Report, which contains the appraised value. There is no uniform standard followed in the timing of these events. Anywhere from four weeks to four months elapse between the appraisal month and the earnings announcement date, and the Audit Research Report lags the announcement date by a few weeks. The median time period between the first of the appraisal month and the earnings report date for firms in our sample is 68 trading days, and the median time period between the earnings report date and the secondary report date is 38 trading days.

To investigate the impact of the arrival of private information on insider trading, we follow John and Lang (1991) and first compute standardized measures of insider trading intensity. These measures reflect net insider trading for the period between the appraisal and the announcement date as well as a holdout period of six months starting two years before the appraisal date. ${ }^{19}$ The first measure, denoted ISPI1, deals with the aggregate number of insider trades, while the second measure, denoted ISPI2, focuses alternatively on the dollar volume of insider trades. Mathematically,
$I S P I 1=(N P-N S) /(N P+N S)$,
$-1 \leq|S P| 1 \leq 1$,
$I S P I 2=(D S P-D S S) /(D S P+D S S)$,
$-1 \leq \mid \mathrm{SPI} 2 \leq 1$

where NP/NS is the aggregate number of insider purchases/sale transactions in period $t$ and DSP/DSS is the dollar amount of insider purchases/sales in time period $t$.

The purpose of the standardization is to scale for the size effect, because firms with more insiders have more insider trading, and to correct for any biases that may exist in insider trading, since Rozeff and Zaman (1988) find a positive bias with respect to net insider buying that may lead to tradinginduced prediction errors. Both ISPI1 and ISPI2 are bounded above by 1 and below by - 1 .

To compute the impact of the reappraisals, we estimate abnormal returns during each of the time periods in the information revelation sequence using a market model with parameters estimated from daily returns starting 120 days before the beginning of the appraisal month and ending 11 days before:

$A R_{j t}=R_{j t}-\left(a_{j}+\beta_{j} R_{m t}\right)$

\footnotetext{
${ }^{19}$ The year and a half preceding the appraisal date is likely to be contaminated by a bias toward insider buying since insiders in undervalued firms are more likely to choose to have themselves reappraised.
} 
where $A R_{j t}$, is the abnormal return for firm; on day $t$, at and 0 , are the market model parameters, and $R_{m t}$ is the return on the value-weighted CRSP index on day $t^{20}$

In addition to examining the abnormal return around the three significant events (i.e., the appraisal, the public announcement, and the secondary announcement), we also compute two measures of cumulated returns. The first, which we use to measure the leakage of private information, is obtained by cumulating the return starting on the first trading day of the appraisal month and continuing through the public announcement (earnings report):

$I A R_{j}=\sum_{t=t_{a}}^{t_{e}-1} R_{j t}$

where $t_{a}$ is the first trading day of the appraisal month, $t_{e}$ is the earnings announcement date, and IAR is the cumulated return for firm $\mathrm{j}$. The second measure that we compute cumulates the return from the earnings announcement date to the day preceding the secondary announcement date:

$P A R_{j}=\sum_{t=t_{e}}^{t_{s}-1} R_{j t}$

where $t_{s}$ is the report date for the Audit Research Report and $\mathrm{PAR}_{\mathrm{j}}$ is the cumulated return for firm $j$. This is used to evaluate the cumulated effect of the public announcement of the appraisal.

\section{Rational Insiders/Outsiders and Abnormal Returns}

There is clear evidence in Table 4 that there are significant differences between REITs that choose to reappraise themselves and REITs that do not. If insiders and outsiders are rational about incorporating these expectations into their behavior, there is likely to be a selection bias. There are two broad approaches for dealing with this bias. Malatesta and Thompson (1985) present a model of stock price reactions to partially anticipated events, where they incorporate stock price movements in periods when no event occurs to estimate the economic importance of the event. In their model, the returns on a stock can be written as

$$
\left(R_{j t}-R_{f t}\right)=\alpha_{j}+\beta_{j}\left(R_{m t}-R_{f t}\right)+\gamma_{j} d_{j t}+e_{j t}
$$

where $R_{j t}$ is the rate of return to firm $j$ at time $t, R_{m t}$ is the rate of return to market portfolio at time $t, R_{f t}$ is the risk-free rate at time $t$, and $d_{j t}$ equals unity if an event occurs at $t$ and zero otherwise. Malatesta and Thompson (1985) assume that events occur at a constant frequency $q_{j}$ per period, and that the

\footnotetext{
${ }^{20}$ Alternative approaches were used to estimate abnormal returns with no qualitative change in our conclusions.
} 
expected economic impact $v_{j}$ of the event is constant. Under the assumption that events are partially anticipated and that their expected economic impacts are positive, their model yields three hypotheses.

- $\quad H 1: \alpha_{j}=q_{j} v_{j}<0$; tests the joint hypothesis that the economic impact of the event is positive and that acquisition attempts are partially, but not perfectly, anticipated.

- $H 2: \Upsilon_{j}=v_{j}>0$; tests the hypothesis that the expected economic impact of the event is positive.

- H3: $\alpha_{j}+\gamma_{j}=\left(1-q_{j}\right) v_{j}>0$; tests the hypothesis that the expected announcement effect is positive if the expected economic impact is positive.

We use the Malatesta-Thompson approach to examine the extent to which reappraisals, in aggregate, are good news and the degree to which they are anticipated by investors. To apply the approach, we collected monthly return data from January 1983 to December 1989 for each firm in our sample and for the value-weighted NYSE composite index. Three dummy variables were defined:

$$
\begin{aligned}
& d_{a j t}= \begin{cases}1, & \text { if an appraisal is completed during the month, } \\
0, & \text { otherwise; }\end{cases} \\
& d_{e j t}= \begin{cases}1, & \text { if an earnings report containing an appraisal is } \\
\text { released during the month, } & \text { otherwise; }\end{cases} \\
& d_{r j t}= \begin{cases}1, & \text { if a secondary report containing an appraisal is } \\
\text { released during the month, }\end{cases}
\end{aligned}
$$

The regression described in Equation (4) was run using each of these dummy variables separately for each firm in the sample and the crosssectional averages of the regression coefficients are reported in Table 5. 


\begin{tabular}{|c|c|c|c|c|c|c|c|c|}
\hline \multirow{2}{*}{$\begin{array}{l}\text { Coeffi- } \\
\text { cient }\end{array}$} & \multirow{2}{*}{$\begin{array}{c}\text { No. } \\
\text { of } \\
\text { esti- } \\
\text { mates } \\
J\end{array}$} & \multirow{2}{*}{$\begin{array}{l}\text { Average } \\
\text { estimate' }\end{array}$} & \multirow[b]{2}{*}{$\%$ positive $^{2}$} & \multirow{2}{*}{$\begin{array}{c}\text { Average } \\
t \text {-statistic }\end{array}$} & \multicolumn{2}{|c|}{ No. significant (\%) } & \multirow[b]{2}{*}{$F$-tests } & \multirow[b]{2}{*}{ DF } \\
\hline & & & & & Positive & Negative & & \\
\hline \multicolumn{9}{|c|}{ Reappraisal completed } \\
\hline$\alpha$ & 35 & -0.00105 & 45.71 & -0.17 & 11.43 & 11.43 & 2.33 & 1,2835 \\
\hline$\beta$ & 35 & 0.51199 & $97.14^{*}$ & $3.26^{*}$ & 71.43 & 0.00 & $14.82^{*}$ & 1,2835 \\
\hline$\gamma$ & 35 & 0.00345 & $68.57^{* *}$ & $0.67^{*}$ & 11.43 & 2.86 & $5.94 * *$ & 1,2835 \\
\hline$\alpha+\gamma$ & 35 & 0.00229 & 54.29 & $0.34^{* *}$ & 11.43 & 5.71 & $4.85 * *$ & 1,2835 \\
\hline \multicolumn{9}{|c|}{ Earnings report } \\
\hline$\alpha$ & 35 & -0.00100 & 54.29 & -0.10 & 11.43 & 8.57 & 1.03 & 1,2835 \\
\hline$\beta$ & 35 & 0.50655 & $97.14^{*}$ & $3.25^{*}$ & 80.00 & 0.00 & $14.30^{*}$ & 1,2835 \\
\hline$\gamma$ & 35 & -0.00053 & 54.29 & -0.10 & 14.29 & 17.14 & 3.67 & 1,2835 \\
\hline$\alpha+\gamma$ & 35 & -0.00153 & 60.00 & 0.20 & 11.43 & 11.43 & 2.56 & 1,2835 \\
\hline \multicolumn{9}{|c|}{ Secondary report } \\
\hline$\alpha$ & 35 & -0.00119 & 54.29 & -0.19 & 11.43 & 8.57 & 1.43 & 1,2835 \\
\hline$\beta$ & 35 & 0.51164 & $94.29^{*}$ & $3.22^{*}$ & 80.00 & 0.00 & $14.54^{*}$ & 1,2835 \\
\hline$\gamma$ & 35 & 0.00229 & 57.14 & 0.12 & 11.43 & 8.57 & 0.73 & 1,2835 \\
\hline$\alpha+\gamma$ & 35 & 0.00110 & 54.29 & 0.22 & 8.57 & 8.57 & 0.95 & 1,2835 \\
\hline
\end{tabular}

$$
\left(R_{j t}-R_{j t}\right)=\alpha_{j}+\beta_{j}\left(R_{m t}-R_{f}\right)+\gamma d_{i t}+e_{j t}
$$

The rates of returns to firm $j$ and the value-weighted market portfolio are denoted by $R_{f i}$ and $R_{r m}$ while $R_{j t}$ denotes the riskless interest rate. $d_{j r}$ equals 1 if firm $j$ had an event (reappraisal completed, earnings announcement with reappraisal or secondary announcement) completed during period $t$ and equals 0 otherwise. Estimates of $\alpha, \beta$, and $\gamma$ are based upon 84 monthly return observations for each of the 37 REITs that had reappraisals during the period starting January 1983 and ending December 1989.

' The coefficients reported here are the average coefficients from 35 firm-specific time-series regres. sions.

: Percentage of 35 firm-specific regression coefficients that are positive.

'The average $t$-statistic across 35 firm-specific regressions is reported. Assuming the coefficients are independent across firms, this is approximately normally distributed with standard deviation = $1 / \sqrt{35}=0.16$

Assuming cross-sectional independence and that the average coefficient is zero, $\Sigma \alpha_{j} / \Sigma \sigma^{2}\left(\boldsymbol{\alpha}_{i}\right)$ is distributed $F(1,2835)$.

- Significant at the .01 level.

* Significant at the 05 level.

The intercept is negative for all three events - the reappraisal, the earnings report, and the secondary report. However, the intercepts are small and statistically insignificant (the average ${ }^{\wedge}$-statistic is not significantly different from zero). The coefficient on the dummy variable for the reappraisal is positive, suggesting that reappraisals are generally considered as "good" news, and the average fstatistic is statistically significant. The average coefficient on the dummy variable for the earnings report is negative, but of the 36 firm-specific regressions only 17 have positive coefficients, suggesting that earnings reports do not provide significant information to financial markets about appraisals. The dummy variable for the secondary report has, on average, a positive coefficient, but the ${ }^{\wedge}$-statistics are generally not significant. The average f-statistics for the sum of the intercept and the dummy coefficient, used to test the bias-adjusted announcement effect (Hypothesis H3 in the Malatesta-Thompson framework), are not significant for the earnings and secondary reports but are significant at the 5 percent level for the reappraisal. In summary, the effect of REIT appraisals on returns seems to be small. Real estate reappraisals, on average, seem to convey good news to financial markets, but the subsequent earnings and secondary reports seem to convey little new information. 
The other approach to dealing with selection bias is from the literature on limited dependent variables. Acharya $(1988,1989)$ extends the sequential signaling equilibrium in Harris and Raviv (1985) to develop consistent estimators of abnormal returns in event studies. Eckbo, Maksimovic, and Williams (1990) extend this approach to cover cross-sectional regressions of announcement effects on exogenous variables. They point out that standard OLS and GLS estimators are inconsistent when the event is voluntary and investors are rational, and suggest consistent maximum-likelihood estimators of coefficients, which they apply to horizontal mergers. We apply the two-step approach described in Acharya to take into account the potential biases induced by the fact that appraisals are voluntary events initiated by insiders in REITs. In the first stage, we estimate the prior probability (<pj) of an appraisal for a REIT from a probit analysis, run on all REITs with data available on an annual basis from 1982 to 1989, using the independent variables listed in Table 4-the book value of total assets, the average quarterly trading volume, the price-earnings ratio, the price-book value ratio, and the debtequity (D/E) ratio. The results are summarized in Table 6 for each year of the sample.

As in Table 4, it is clear that firms with low price-book value and price-earnings ratios are much more likely to choose to have appraisals than other firms. The probabilities $\left(\emptyset_{j}\right)$ estimated from these probit analyses are used in conjunction with the cumulative probabilities $\left(\Phi_{\mathrm{j}}\right)$, to estimate $\Upsilon_{\mathrm{j}}$ and $\widehat{\gamma}_{J}$, where $\gamma_{j}=\emptyset_{j} / \Phi_{j,} \quad \widehat{y}_{J}=\emptyset_{j} /\left(1-\Phi_{j}\right)$

In the second stage, we regress excess returns estimated during the appraisal period $(\epsilon)$ against $\Upsilon_{j}$ and $\widehat{y_{J}}$ :

$$
\epsilon=\mu+\pi\left(\gamma_{j}-\hat{\gamma}_{j}\right)+v
$$

The coefficient $\pi$ in the regression is a measure of the market response to the announcement of an appraisal by a REIT, conditioned on insiders being rational in choosing to have an appraisal. A positive $w$ implies that the appraisal effect $\left(\pi \gamma_{j}\right)$ is positive, and the mean of this appraisal effect is the cumulated abnormal return. While the Malatesta- Thompson approach measures the difference between expected abnormal returns due to the event and the expected abnormal returns due to the nonevent, the limiteddependent variable approach explicitly allows for three aspects of corporate events - that these events are decided by insiders, that outsiders can estimate the probabilities of these events using public information, and that these probabilities can change over time. The measure of abnormal returns from Equation (5) should therefore be free from the sample bias that standard event study methodology 
exposes us to and that persists in the Malatesta- Thompson approach. The results of the regressions, for positive and negative appraisals, are reported in Table 7.

We examine excess returns during three periods - the month of the appraisal, the 20 trading days around the earnings announcement that contains the appraisal, and the 20 trading days around the secondary report-and estimate the coefficients in Equation (5). For positive appraisals, the regression coefficient $(\pi)$ is positive during all three periods. However, the t-statistics indicate statistical significance only for returns in the earnings report period. These results indicate that positive appraisals elicit positive abnormal returns when they are reported in earnings reports, even though these reports reach financial markets several months after insiders receive the appraisal value. For negative appraisals, the regression coefficient $(x)$ is negative in all three periods, but is statistically significant only in the appraisal month. The negative abnormal returns in the appraisal month indicate that insiders trade on their private information and affect prices in the process. The public announcement of the negative appraisal does not elicit much response from markets, suggesting that investors have incorporated the information into prices prior to their public release. The disparity in market response to positive and negative appraisals will be analyzed in more detail in the next section.

Table 6

Estimation of probability that a firm is appraised (1982-1989)

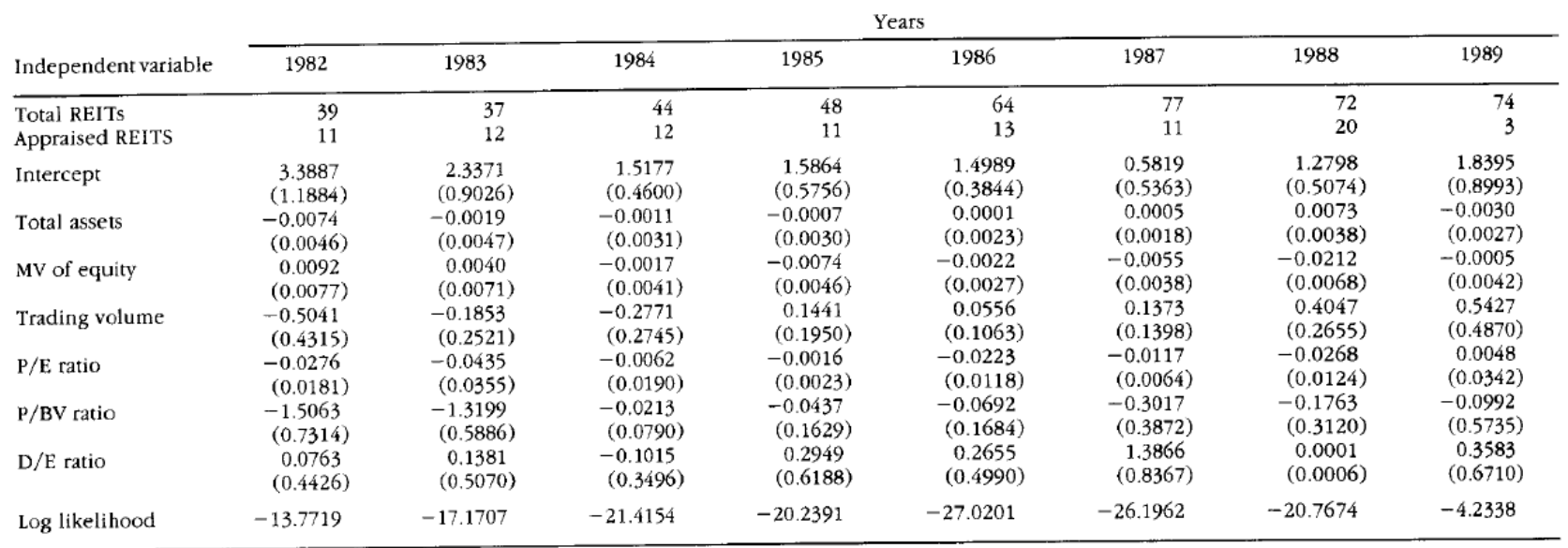

$\phi_{f}=f($ Total assets, MV of equity, volume, $\mathrm{P} / \mathrm{E}$ ratio, $\mathrm{P} / \mathrm{BV}$ ratio, $\mathrm{D} / \mathrm{E}$ ratio).

The probability that a firm will be appraised is estimated using a probit analysis on all REITs for each year from 1982 to 1989 , with the independent variables listed above. The maximum-likelihood estimates of regression parameters is reported below for each of the independent variables for each year of the analysis. The standard errors are in parentheses below the estimates. 
Table 7

Estimation of excess returns associated with appraisals

\begin{tabular}{|c|c|c|c|c|c|}
\hline \multicolumn{3}{|c|}{ Negative appraisals } & \multicolumn{3}{|c|}{ Positive appraisals } \\
\hline $\mathrm{APPRET}_{i}=$ & $\begin{array}{c}-0.029762 \\
(-1.705)\end{array}$ & $\begin{array}{c}-0.055325\left(\gamma_{\prime}-\hat{\gamma}_{l}\right) \\
(-2.121)\end{array}$ & APPRET $_{i}=$ & $\begin{array}{c}-0.009695 \\
(-1.593)\end{array}$ & $+\underset{(1.638)}{0.014196\left(\gamma_{j}-\hat{\gamma}_{j}\right)}$ \\
\hline CUMRET $_{i}=$ & $\begin{array}{c}-0.032595 \\
(-3.354)\end{array}$ & $\begin{array}{c}-0.000780\left(\gamma_{i}-\hat{\gamma}_{i}\right) \\
(-0.054)\end{array}$ & $\mathrm{CUMRET}_{j}=$ & $\begin{array}{c}0.017637 \\
(3.202)\end{array}$ & $\begin{array}{c}+0.016747\left(\gamma_{j}-\hat{\gamma}_{j}\right) \\
(2.135)\end{array}$ \\
\hline $\operatorname{SECRET}_{j}=$ & $\begin{array}{c}0.003225 \\
(0.582)\end{array}$ & $\begin{array}{c}-0.015447\left(\gamma_{j}-\hat{\gamma}_{j}\right) \\
(-1.166)\end{array}$ & SECRET $_{i}=$ & $\begin{array}{c}0.018589 \\
(2.128)\end{array}$ & $\begin{array}{c}+0.013024\left(\gamma_{j}-\hat{\gamma}_{j}\right) \\
(1.047)\end{array}$ \\
\hline
\end{tabular}

Dependent variable is excess returns; independent variable is function of probit probabilities. APPRET $_{n}$, Cumulated abnormal returns during the month of the appraisal; CUMRET, cumulated abnormal return from trading day -10 to +10 (day 0 is the earnings report date); $\mathrm{SECRET}_{j}$, cumulated abnormal return from trading day -10 to +10 (day 0 is the secondary report date).

The probabilities $\left(\phi_{i}\right)$ estimated from these probit analyses are used in conjunction with the cumulative probabilities $\left(\Phi_{j}\right)$, to estimate $\gamma_{j}$ and $\hat{\gamma}_{j}$, where

$$
\gamma_{j}=\phi_{j} / \Phi_{j}, \quad \hat{\gamma}_{j}=-\phi_{j} /\left(1-\Phi_{j}\right) \text {. }
$$

\section{Results}

The results are presented in five parts. First, we compute the abnormal returns around the earnings announcement date to examine whether public announcements of favorable (unfavorable) appraisals are accompanied by positive (negative) market responses. Second, we estimate the abnormal returns around the secondary report date, when the Audit Realty Report comes out, to see if the republication of information that is already public has any informational value. Third, we report on the cumulated abnormal returns in the appraisal month, the period between the appraisal month and the earnings report date, and the period between the earnings report and secondary report dates to evaluate the effects of insider trading. Fourth, we examine the extent of insider trading both prior to and following reappraisals using insider filings with the SEC. Finally, we evaluate the effects of appraisal values and insider trading on abnormal returns in the appraisal and earnings announcement periods.

The sequence of events described here is like the sequence in Eckbo, Maksimovic, and Williams (1990). They estimate cumulated abnormal returns around merger announcements and attempt to relate the announcement effects to exogenous characteristics of firms and industries. They point out the problems of truncation bias and bias induced by prior anticipation of insider actions on the measurement of cumulated abnormal returns using standard OLS or GLS techniques and correct for these biases by using maximum-likelihood estimators. We, therefore, steer away from cross-sectional regressions in trying to explain announcement effects around the release of reappraisal information and attempt to provide bias-corrected announcement period returns at each stage. 


\section{Market Reaction to the Public Announcement of Appraisal Values}

In Table 8, we examine market reactions to earnings announcements with real estate appraisals in them. We use the difference between the appraised value and the market price on the earnings announcement date as a measure of whether the appraisal is favorable (appraised value $>$ market price) or unfavorable (appraised value < market price). The cross-sectional averages (and the corresponding tstatistics for significance) of the abnormal returns, starting 10 days before the earnings report and ending 10 days after, are reported in Table 8.

Table 8 shows no evidence of any significant announcement day effects associated with the appraisals. Negative appraisals are accompanied by positive abnormal returns (though the ${ }^{\wedge}$-statistic reveals no significance) on the announcement date, while positive appraisals have abnormal returns close to zero on the report date. If returns are cumulated over the announcement period (days - 10 to +10 around the earnings report date), then positive appraisals are associated with marginally significant positive abnormal returns but negative appraisals are not associated with significant negative abnormal returns. When we correct the cumulated return for sample bias (using the limited dependent variable approach), our findings do not change materially. ${ }^{21}$ The cumulated abnormal return associated with positive appraisals declines to 1.14 percent and the t-statistics become insignificant. This return behavior cannot be explained by surprises in the earnings announcements that accompany the appraisals, since there is little correlation between the earnings surprise and whether the appraisal is positive or negative. ${ }^{22}$

The absence of an announcement effect around the public release of appraisal information is not necessarily inconsistent with our argument in the prior section that appraisals do have informational value, since at least two potential explanations exist for the lack of correlation between the return behavior and the nature of the appraisal. First, investors may not be aware of the appraisals and hence not react to them until they are provided with the information by external services because REITs do not emphasize appraisal values in their initial earnings announcements. ${ }^{23}$ Since REITs are much more likely to deemphasize negative appraisals than positive appraisals, this may also help to explain why positive appraisals are associated with positive abnormal returns while negative appraisals do not have a

\footnotetext{
${ }^{21}$ We obtained sample-bias adjusted returns using both the limited dependent variable approach as well as the Malatesta-Thompson approach. Since the results are similar, only the results from the former are reported. 22 Of the 28 negative appraisals, 13 were accompanied by positive earnings surprises (current EPS > EPS same quarter last year) and 15 by negative earnings surprises. Of the 26 positive appraisals, 12 were accompanied by positive earnings surprises and 14 by negative earnings surprises.

${ }^{23}$ Of the 77 earnings reports that appeared on the broadtape, we found only three instances where appraisal values were reported either on a per-share or total value basis. All three reports contained positive appraisals.
} 
corresponding negative impact on returns. Second, since the appraisal value is known well in advance of the earnings report to insiders in the firm, prices may adjust to the information in them prior to their public release if these insiders trade on the information. 
Table 8

Abnormal returns around earnings announcements and audit realty reports: Positive and negative reappraisals (1982-1989)

\begin{tabular}{|c|c|c|c|c|c|c|c|c|}
\hline \multirow[b]{3}{*}{ Day } & \multirow{2}{*}{\multicolumn{2}{|c|}{ Earnings report }} & \multicolumn{2}{|c|}{$\begin{array}{c}\text { Positive vs. } \\
\text { negative }\end{array}$} & \multirow{2}{*}{\multicolumn{2}{|c|}{ Audit report }} & \multicolumn{2}{|c|}{$\begin{array}{c}\text { Positive vs } \\
\text { negative }\end{array}$} \\
\hline & & & \multirow{2}{*}{$\begin{array}{l}\text { t-sta- } \\
\text { tistic }\end{array}$} & \multirow[b]{2}{*}{$x^{2}$} & & & \multirow{2}{*}{$\begin{array}{l}t \text {-sta- } \\
\text { tistic }\end{array}$} & \multirow[b]{2}{*}{$x^{2}$} \\
\hline & Positive' & Negative? & & & Positive & Negative & & \\
\hline No. of reports & 43 & 33 & & & 43 & 33 & & \\
\hline-10 & $\begin{array}{l}-0.4856 \\
(-1.24)\end{array}$ & $\begin{array}{l}-0.3811 \\
(-1.16)\end{array}$ & 0.20 & 0.47 & $\begin{array}{l}0,2174 \\
(0.67)\end{array}$ & $\begin{array}{l}-0.3062 \\
(-1.28)\end{array}$ & 1.29 & 3.29 \\
\hline-9 & $\begin{array}{l}0.5409 \\
(1.66)\end{array}$ & $\begin{array}{c}0.5366 \\
(1.00)\end{array}$ & 0,01 & 0.35 & $\begin{array}{l}0.2905 \\
(0.51)\end{array}$ & $\begin{array}{r}0.0697 \\
(0.29)\end{array}$ & 0.36 & 0.12 \\
\hline-8 & $\begin{array}{l}0.2883 \\
(0.78)\end{array}$ & $\begin{array}{l}-0.3462 \\
(-1.12)\end{array}$ & 1.31 & 2.66 & $\begin{array}{l}-0.1932 \\
(-0.66)\end{array}$ & $\begin{array}{l}-0.2460 \\
(-0.96)\end{array}$ & 0.14 & 0.05 \\
\hline-7 & $\begin{array}{l}-0.2518 \\
(-1.23)\end{array}$ & $\begin{array}{r}0.0071 \\
(0.03)\end{array}$ & 0.86 & 0.96 & $\begin{array}{c}0.6146 \\
(1.44)\end{array}$ & $\begin{array}{c}0.1148 \\
(0.54)\end{array}$ & 1.05 & 0.27 \\
\hline-6 & $\begin{array}{l}1.0419 \\
(2.50)^{*}\end{array}$ & $\begin{array}{l}-0.0600 \\
(-0.21)\end{array}$ & $2.19^{* *}$ & 4.73 & $\begin{array}{c}-0.6709 \\
(-2.21)^{*}\end{array}$ & $\begin{array}{l}0.1147 \\
(0.22)\end{array}$ & 1.32 & 0.05 \\
\hline-5 & $\begin{array}{l}-0.2491 \\
(-0.60)\end{array}$ & $\begin{array}{l}-0.3860 \\
(-1.58)\end{array}$ & 0.26 & 0.01 & $\begin{array}{c}0.0828 \\
(0.21)\end{array}$ & $\begin{array}{c}0.4314 \\
(1.25)\end{array}$ & 0.66 & 0.51 \\
\hline-4 & $\begin{array}{l}-0.1217 \\
(-0.42)\end{array}$ & $\begin{array}{l}-0.2655 \\
(-0.89)\end{array}$ & 0.34 & 0.07 & $\begin{array}{r}0.1427 \\
(0.42)\end{array}$ & $\begin{array}{c}0.1642 \\
(0.60)\end{array}$ & 0.05 & 0.08 \\
\hline-3 & $\begin{array}{r}0.4517 \\
(1.79)\end{array}$ & $\begin{array}{r}0.1295 \\
(0.36)\end{array}$ & 0.74 & 0.75 & $\begin{array}{c}-0.2469 \\
(-0.63)\end{array}$ & $\begin{array}{l}-0.1959 \\
(-1.14)\end{array}$ & 0.12 & 0.00 \\
\hline-2 & $\begin{array}{r}0.0811 \\
(0,16)\end{array}$ & $\begin{array}{c}0.2598 \\
(0.86)\end{array}$ & 0.31 & 0.10 & $\begin{array}{l}-0.1778 \\
(-0.38)\end{array}$ & $\begin{array}{l}-0.6256 \\
(-3.00)^{*}\end{array}$ & 0.88 & 1.34 \\
\hline-1 & $\begin{array}{l}-0.0269 \\
(-0.06)\end{array}$ & $\begin{array}{l}-0.4182 \\
(-1.08)\end{array}$ & 0.65 & 0.04 & $\begin{array}{r}0.4857 \\
(1.02)\end{array}$ & $\begin{array}{c}0.0718 \\
(0.16)\end{array}$ & 0.63 & 0.51 \\
\hline 0 & $\begin{array}{r}0.0806 \\
(0.29)\end{array}$ & $\begin{array}{l}0.4614 \\
(1.22)\end{array}$ & 0.81 & 0.69 & $\begin{array}{l}-0.1319 \\
(-0.33)\end{array}$ & $\begin{array}{l}0.5374 \\
(1.32)\end{array}$ & 1.39 & 1.92 \\
\hline 1 & $\begin{array}{l}0.3081 \\
(0.93)\end{array}$ & $\begin{array}{c}0,0423 \\
(0.12)\end{array}$ & 0.54 & 0.59 & $\begin{array}{l}-0.0955 \\
(-0.23)\end{array}$ & $\begin{array}{r}-0.0611 \\
(0.19)\end{array}$ & 0.30 & 0.74 \\
\hline 2 & $\begin{array}{l}0.3620 \\
(0.98)\end{array}$ & $\begin{array}{c}0.8724 \\
(1.91)\end{array}$ & 0.87 & 0.14 & $\begin{array}{l}-0.0393 \\
(-0.12)\end{array}$ & $\begin{array}{l}-0.3388 \\
(-1.65)\end{array}$ & 0.80 & 0.25 \\
\hline 3 & $\begin{array}{l}-0.0915 \\
(-0.25)\end{array}$ & $\begin{array}{l}-0.2991 \\
(-0.85)\end{array}$ & 0.41 & 1.07 & $\begin{array}{c}0.0152 \\
(0.07)\end{array}$ & $\begin{array}{l}-0.3791 \\
(-0.91)\end{array}$ & 0.84 & 1.66 \\
\hline 4 & $\begin{array}{l}0.1182 \\
(0.39)\end{array}$ & $\begin{array}{r}0.0645 \\
(0.17)\end{array}$ & 0.11 & 0.00 & $\begin{array}{l}0.1513 \\
(0.50)\end{array}$ & $\begin{array}{l}-0.0557 \\
(-0.17)\end{array}$ & 0.46 & 0.28 \\
\hline 5 & $\begin{array}{c}0.0316 \\
(0.11)\end{array}$ & $\begin{array}{c}0.0154 \\
(0.07)\end{array}$ & 0.04 & 0.00 & $\begin{array}{r}0.4754 \\
(1.34)\end{array}$ & $\begin{array}{l}-0.3732 \\
(-1.35)\end{array}$ & 1.88 & 1.19 \\
\hline 6 & $\begin{array}{l}-0.7695 \\
(-2.19) \cdots\end{array}$ & $\begin{array}{l}-0.0045 \\
(-0.01)\end{array}$ & 1.63 & 1.04 & $\begin{array}{l}-0.4551 \\
(-1.22)\end{array}$ & $\begin{array}{r}0.3940 \\
(1.12)\end{array}$ & 1.65 & 1,09 \\
\hline 7 & $\begin{array}{l}-0.1745 \\
(-0.87)\end{array}$ & $\begin{array}{r}0.3283 \\
(1.37)\end{array}$ & 1.60 & 1.22 & $\begin{array}{l}-0.2052 \\
(-0.41)\end{array}$ & $\begin{array}{l}-0.2330 \\
(-0.92)\end{array}$ & 0.05 & 0.61 \\
\hline 8 & $\begin{array}{l}0.3228 \\
(0.95)\end{array}$ & $\begin{array}{l}-0.2650 \\
(-1.20)\end{array}$ & 1.45 & 0.63 & $\begin{array}{r}0.1165 \\
(0.32)\end{array}$ & $\begin{array}{c}0.0166 \\
(0.07)\end{array}$ & 0.23 & 0.16 \\
\hline 9 & $\begin{array}{l}0.1720 \\
(0.72)\end{array}$ & $\begin{array}{l}-0.1044 \\
(-0.32)\end{array}$ & 0.69 & 0.05 & $\begin{array}{l}0.0334 \\
(0.10)\end{array}$ & $\begin{array}{l}-0.0891 \\
(-0.41)\end{array}$ & 0.30 & 0.01 \\
\hline 10 & $\begin{array}{l}0.8569 \\
(2.41)^{*}\end{array}$ & $\begin{array}{l}-0.2686 \\
(-1.09)\end{array}$ & $2.60^{*}$ & $6.46^{\circ}$ & $\begin{array}{c}0.3863 \\
(0.93)\end{array}$ & $\begin{array}{r}0.7335 \\
(1.70)\end{array}$ & 0.58 & 0.04 \\
\hline $\begin{array}{l}-10 \text { to }+10 \\
\text { Total }\end{array}$ & $\begin{array}{l}2.4855 \% \\
(2.09) *\end{array}$ & $\begin{array}{l}-0.0814 \% \\
(-0.07)\end{array}$ & 1.68 & 0.70 & $\begin{array}{l}1.9486 \\
(1.60)\end{array}$ & $\begin{array}{c}0.3034 \\
(0.23)\end{array}$ & 0.93 & 0.92 \\
\hline $\begin{array}{l}-10 \text { to }+10 \\
\text { Bias Adj.' }\end{array}$ & $\begin{array}{l}1.2507 \% \\
(1.75)\end{array}$ & $\begin{array}{l}-0.0516 \% \\
(-0.07)\end{array}$ & 1.26 & & $\begin{array}{l}1.0624 \\
(1.08)\end{array}$ & $\begin{array}{l}-0.8544 \\
(-1.20)\end{array}$ & 1.31 & \\
\hline
\end{tabular}

The announcement date is day 0 ; the excess returns are estimated relative to the market model with parameters estimated from 120 trading days immediately preceding the beginning of the

appraisal month. The cross-sectional standard errors are used to calculate $t$-statistics, which are reported in parentheses under the cross-sectional averages.

' A positive appraisal is one where the appraisal value is greater than the market price, while a negative appraisal is one where the appraisal value is less than the market price.

" The $t$-statistic tests the hypothesis that the means of the two groups are equal.

"The $\chi^{\prime}$-statistic is a nonparametric test based upon a Wilcoxon rank sum test.

- The bias-adjusted abnormal returns are estimated using the limited dependent variable approach, separately for positive and negative appraisals.

* Significant at .01 level.

* Significant at .05 level. 


\section{Market Reaction to the Secondary Announcement of Appraisal Values}

If the first explanation holds, then the release of the appraisal information by Audit Investments to its subscribing customers should be accompanied by price changes consistent with the content of the appraisal. We report the cross-sectional averages of the abnormal returns, starting 10 days before the secondary report date and ending 10 days after, in Table 8. Little evidence of a significant market response to secondary reports is revealed in Table 8. Neither positive nor negative appraisals are associated with statistically significant abnormal returns on the announcement date. The cumulative return over all the trading days $(-10$ to +10$)$ is positive for both favorable appraisals and unfavorable appraisals, but the t-statistics are not significant for either. These findings are unaffected by the adjustment for sample bias, using the limited dependent variable approach.

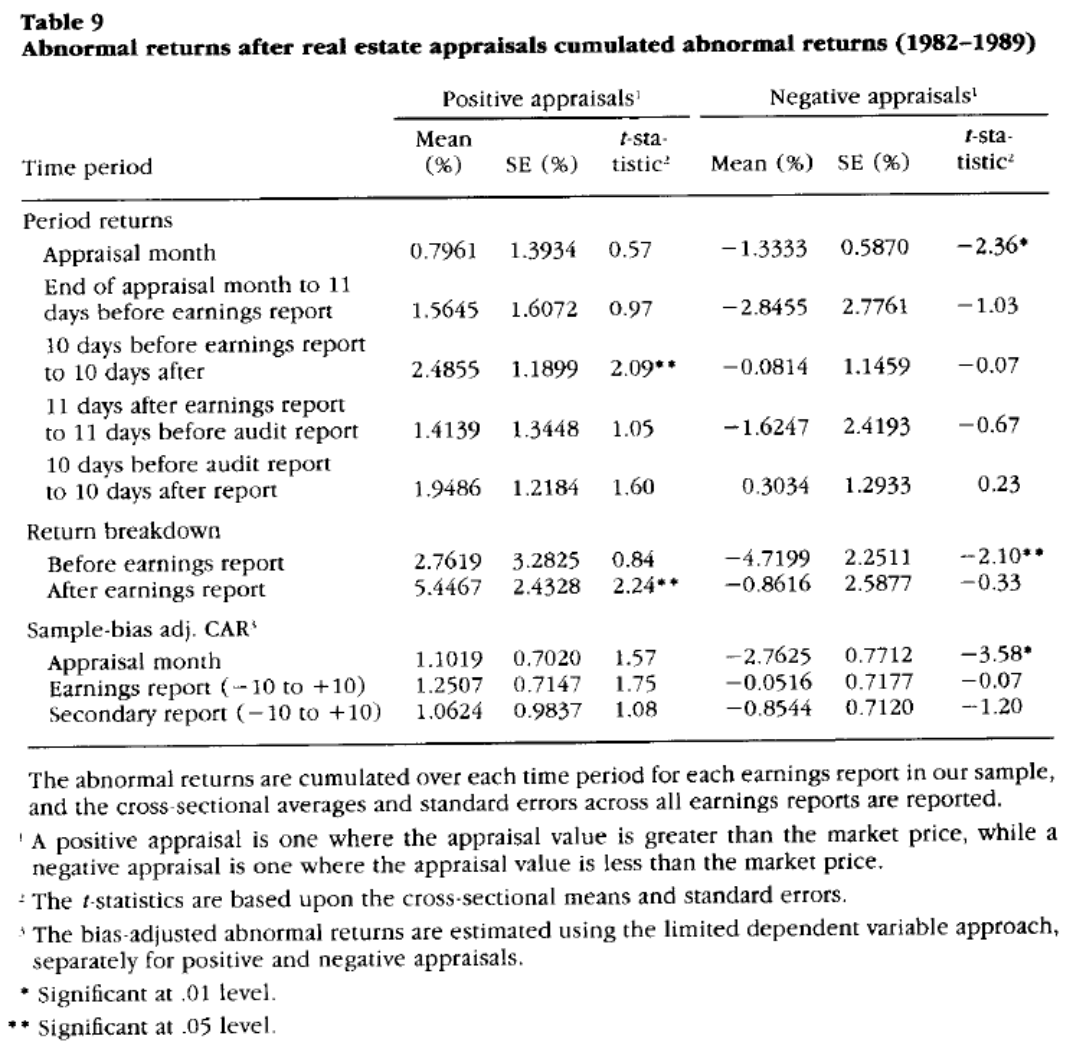

Abnormal Returns Prior to the Public Release of Appraisal Values

If insider holdings increase (decrease) in response to "good (bad) news" private information, and this signal elicits a positive (negative) price response, then changes in insider holdings convey the information contained in the appraisal to financial markets. The actual announcement of the appraisal value may then have a much smaller impact on market prices. To examine whether this explanation 
holds, we compute and report the cumulated abnormal return over each of the following sequential time periods in Table 9 for favorable and unfavorable appraisals: (1) for all the trading days in the month in which the appraisal is made; (2) from the end of the appraisal month to 11 days before the earnings announcement; (3) from 10 days before the earnings report to 10 days after; (4) from 11 days after the earnings announcement to 11 days before the Audit Research Report; and (5) from 10 days before the Audit Research Report to 10 days after.

The evidence in Table 9 seems to indicate differences in price behavior do exist in response to favorable and unfavorable appraisals. Unfavorable appraisals are followed by significant negative abnormal returns in the appraisal month (with a t-statistic of 2.36), marginal negative abnormal returns in the period between the appraisal month and the earnings report, and insignificant negative returns during the earnings announcement period and the period immediately following the announcement period, with the cumulative returns slightly positive in the period surrounding the secondary report. Correcting for sample bias, using the limited dependent variable approach, results in more negative returns in the appraisal month, but the returns during the earnings and secondary report periods are not significantly different from zero. In contrast, although favorable appraisals are followed by positive abnormal returns in the appraisal month, the returns are small and are not statistically significant. The period between the appraisal month and the earnings report is also characterized by positive abnormal returns of marginal statistical significance. The most significant abnormal returns with favorable reports seem to be earned in the period surrounding the earnings announcement and in the following period. When the correction for sample bias is made, the cumulated returns are not significantly different from zero in the appraisal month and during the earnings and secondary reports. ${ }^{24}$ To illustrate this difference further, we estimate the proportion of abnormal returns earned in the period both before and after the earnings report (i.e., before the appraisal was made public) for positive and negative appraisals. For negative appraisals, most of the negative abnormal returns accrue before the earnings report; while for positive appraisals, most of the positive abnormal returns accrue after the earnings report. The

\footnotetext{
${ }^{24}$ We also examined the extent to which the empirical price responses in later stages (i.e., the earnings report and the secondary report) were dependent upon price responses at earlier stages (such as in the reappraisal month) by computing the correlation coefficients between the cumulated returns over each of these periods. The correlation coefficients between returns in the three periods are as follows and suggest a positive dependence:

Appraisal month Earnings report Secondary report

\begin{tabular}{|c|c|c|c|}
\hline $\begin{array}{l}\text { Appraisal month } \\
\text { Earnings report } \\
\text { Secondary report }\end{array}$ & 1.00 & $\begin{array}{l}0.55 \\
1.00\end{array}$ & $\begin{array}{l}0.19 \\
0.56 \\
1.00\end{array}$ \\
\hline
\end{tabular}
}


significant positive abnormal returns in the period between the earnings and the secondary reports for favorable appraisals can be attributed to investors becoming aware, albeit belatedly, of the appraisal value. The reason for the delay in incorporating information in prices may be due to the fact that earnings reports on the newswire, which are used to determine our report dates, often do not contain information on the appraisals.

\section{Insider Trading Prior to the Public Release of Appraisal Values}

The dichotomous response of the market to favorable and unfavorable appraisals may be traced to the nature of the appraisal process. Since REITs choose when they are appraised and who appraises them, an unfavorable appraisal is also likely to be much more of a surprise to insiders than a favorable one, leading presumably to insider selling and negative abnormal returns. Favorable appraisals, on the other hand, confirm insiders' beliefs about their firms' future prospects and should not result in substantial insider trading. This explanation is supported by an examination of insider trading data obtained from insider trading reports filed with the SEC by directors, beneficial owners (more than 10 percent of outstanding equity), and officers of the firm. First, we report on all insider transactions in the six months preceding the appraisal month in panel A of Table 10 for the firms in our sample, classified by the type of appraisal (favorable or unfavorable). There is a clear positive bias in insider trades before both positive and negative reappraisals, with more insider buying than insider selling in the time period. This is consistent with our hypothesis that insiders who believe that their firms are undervalued are much more likely to have them reappraised than insiders in other firms. There also seems to be some evidence of more insider buying prior to positive appraisals than negative appraisals, though the difference between the two classes on this score is not statistically significant. ${ }^{25}$

To examine how the reappraisals affect insiders' views on their firms (and their holdings), we report on insider transactions between the reappraisal month and the earnings reports in panel $B$ of Table 10. There is a dramatic shift toward insider selling after negative appraisals. Of the 68 insider transactions between the month of an unfavorable appraisal and the corresponding earnings report, 48 were open-market sales and six represented disposal by gift. There were only nine open-market purchases during the same period. In contrast, the trend toward insider buying that we noted in Table 10 is strengthened if the appraisal contains positive information. Of the 45 insider transactions reported between the month of a favorable appraisal and the earnings report, there are 13 acquisitions by

\footnotetext{
${ }^{25}$ The insider trading measure for the preappraisal period was 0.3143 for positive appraisals and 0.1923 for negative appraisals. The f-statistic, testing for differences between these two means, was not significant.
} 
exercise of options, 17 acquisitions of shares through a plan, and 10 open-market purchases. There were only five open-market sales. A comparison of the standardized insider trading measures in the appraisal and holdout periods reveals strong support for the hypothesis that insiders trade on appraisals, since insider trading measures following positive (negative) appraisals are significantly greater (lower) than the corresponding statistics for the holdout period.

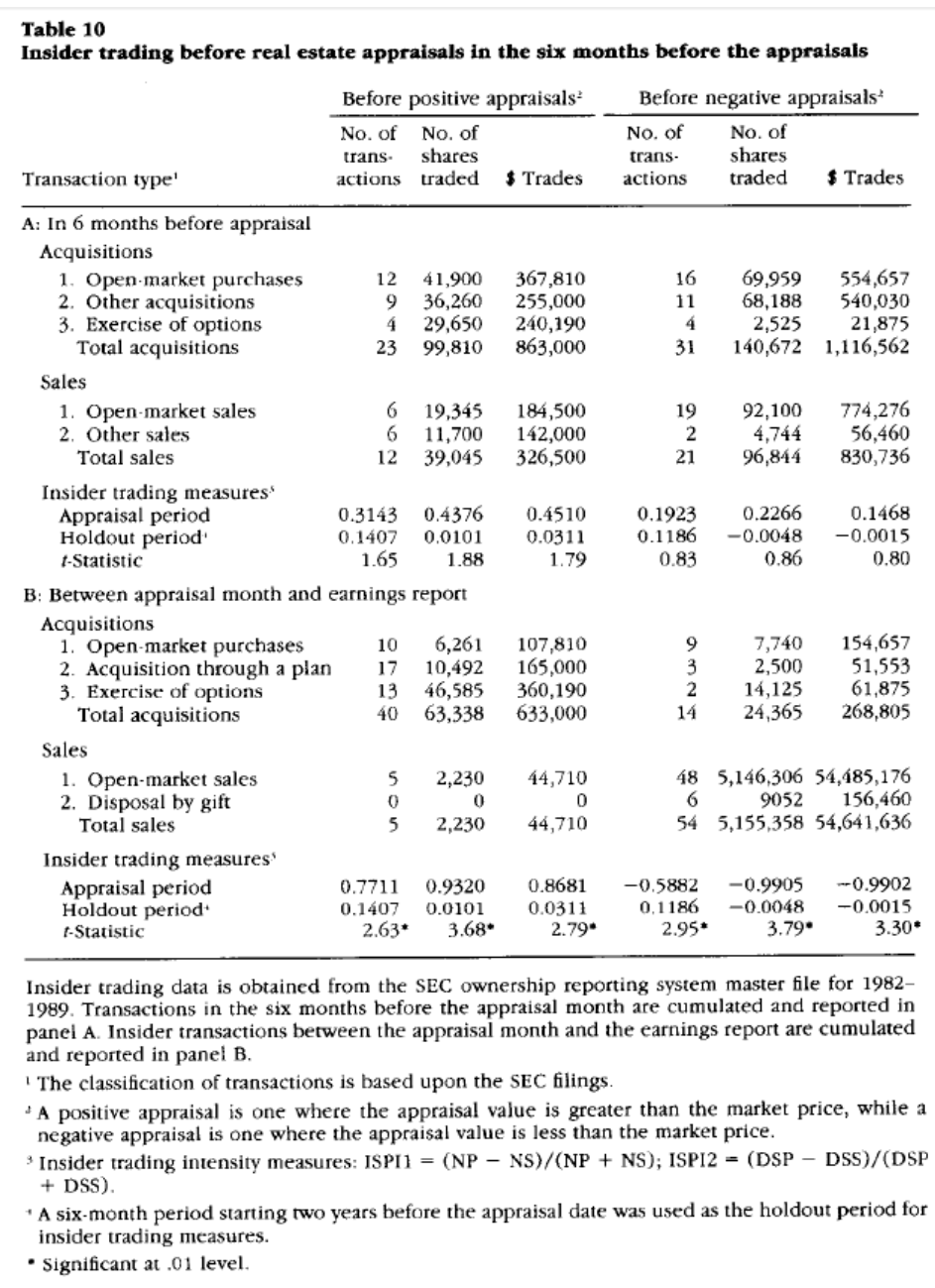

To illustrate the impact of insider trading on excess returns, we classify firms on the basis of the nature of the appraisal (positive or negative) and the net value of insider trading (i.e., whether insider buying exceeds insider selling or vice versa) in Table 11. We report the excess returns in the appraisal period, the earnings announcement period, and the secondary announcement period for each appraisal subgroup and come to the following conclusions. ${ }^{26}$ First, insider trading clearly has an impact on abnormal returns in the appraisal period. For both positive and negative appraisals, appraisals with net

\footnotetext{
${ }^{26}$ We estimated sample-bias adjusted CARs as well. While we have enough observations to estimate the coefficients for the positive appraisal/net insider buying and negative appraisal/net insider selling combinations, we do not have enough observations to estimate coefficients for the other two combinations.
} 
insider selling (insider selling > insider buying) in the period between the appraisal and the earnings announcement are characterized by much more negative returns in the appraisal month than appraisals with net insider buying (with significant F-statistics). Second, net insider trading does not appear to impact on excess returns in the earnings and secondary announcement periods in a significant manner. Third, the excess returns in all three subperiods are more positive following positive appraisals than negative appraisals. Consequently, the results in this table support our proposition that while appraisals contain information, insider trading conveys information about these appraisals to financial markets in the period before they are made public. ${ }^{27}$ The other interesting finding that emerges from Table 11 is that insider trading has a much larger impact on market prices when accompanied by an appraisal.

\section{Conclusion}

REITs that choose to have themselves appraised offer a unique opportunity to examine how private information is used by insiders in these firms. There are several interesting findings that emerge from our study. From our examination of REITs that choose to appraise themselves, we can conclude that insiders are successful in predicting when their firms are undervalued and hire appraisers to communicate this to the market. We establish that appraisals have informational value by analyzing the composition of the appraised REITs, in terms of the number of properties they own, and the number of regions and states that they operate in, and relating it to the divergence of appraised value from market value. This informational value can be traced to appraisers bringing in data from other appraisals, which becomes valuable when combined with the firm's internal data on property performance. Insiders seem to believe this appraised value and trade on it to make a profit, and, in the process, reveal their information to outsiders. Consequently, the public disclosure of appraisals does not elicit a significant response from financial markets.

\section{References}

Acharya, S., 1988, "A Generalized Econometric Model and Tests of a Signalling Hypothesis with Two Discrete Signals," Journal of Finance, 43, 413-429.

\footnotetext{
${ }^{27}$ We also attempted to examine the relationship between the magnitude of insider trading (appraisal outcome) and cumulative abnormal returns during the appraisal period, the earnings report, and the secondary report by regressing the abnormal returns against the appraisal outcome (appraised value - market price) and the insider trading (insider buying - insider selling). While the coefficients are consistent with the results in Table 11 (positive for both appraisal outcome and insider trading), the $t$ statistics are marginal because the number of observations is small.
} 
Acharya, S., 1989, "Insiders' Decision of Corporate Events: A Simple Measure of Expected Abnormal Return, Conditional on Outsiders' Prior Information," working paper, Graduate School of Business Administration, New York University.

Allen, P. R., and C F. Sirmans, 1987, "An Analysis of Gains to Acquiring Firm's Shareholders: The Special Case of REITs," Journal of Financial Economics, 18, 175-184.

Chiang, R., D. C Ling, and P. C. Venkatesh, 1989, "REIT and Earnings and Dividend Announcements," working paper, University of Miami.

Copeland, T. E., and W. H. Lee, 1988, "Exchange Offers and Stock Swaps-A Signalling Approach: Theory and Evidence," working paper, UCLA.

Copeland, T. E., and D. Mayers, 1982, "The Value Line Enigma (1965-78): A Case Study of Performance Evaluation Issues," Journal of Financial Economics, 10, 289-321.

Cornell, B., and E. Sirri, 1992, "The Reaction of Investors and Stock Price to Insider Trading," working paper, UCLA.

Eckbo, B. E., V. Maksimovic, and J. Williams, 1990, "Consistent Estimation of Cross-Sectional Models in Event Studies," Review of Financial Studies, 3, 343-366.

Finnerty, J. E., 1976, "Insiders and Market Efficiency," Journal of Finance, 31, 1141-1148.

Givoly, D., and D. Palmon, 1985, "Insider Trading and the Exploitation of Inside Information: Some Empirical Evidence," Journal of Business, 58, 69-88.

Harris, M., and A. Raviv, 1985, "A Sequential Signalling Model of Convertible Debt Call Policy," Journal of Finance, 40, 1263-1281.

Hirschey, M., and J. K. Zaima, 1989, "Insider Trading, Ownership Structure, and the Market Assessment of Corporate Sell Offs, "Journal of Finance, 44, 971-980.

Hite, G. L., J. E. Owers, and R. C. Rogers, 1984, "The Separation of Real Estate Operations by Spinoff," AREUEA Journal, 12, 318-331.

Howe, J. S., and J. D. Shilling, 1988, "Capital Structure Theory and REIT Security Offerings,"/owrna/ of Finance, 43, 983-993.

Jaffe, J., 1974a, "The Effect of Regulation Changes on Insider Trading," Bell Journal of Economics and Management Science, 5, 93-121.

Jaffe, J., 1974b, "Special Information and Insider Trading," Journal of Business, 47, 410-428.

Jarrell, G. A., and A. B. Poulsen, 1989, "Stock Trading Before the Announcement of Tender Offers: Insider Trading or Market Announcement?" Journal of Law and Economics, 5, 225-248. 
John, K., and L. Lang, 1991, "Insider Trading Around Dividend Announcements: Theory and Evidence," Journal of Finance, 46, 1361-T390.

John, K., and B. Mishra, 1990, "Information Content of Insider Trading Around Corporate Announcements: The Case of Capital Expenditures," Journal of Finance, 45, 835-856.

Keown, A. J., and J. M. Pinkerton, 1981, "Merger Announcements and Insider Trading Activity: An Empirical Investigation," Journal of Finance, 36, 855-869.

Malatesta, P., and R. Thompson, 1985, "Partially Anticipated Events: A Model of Stock Price Reactions with an Application to Corporate Acquisitions," Journal of Financial Economics, 14, 237-250.

Manski, C, 1991, "Regression," Journal of Economic Literature, 29, 34-50.

Palmon, D., and L. J. Seidler, 1978a, "Current Value Reporting of Real Estate Companies and a Possible Example of Market Inefficiency," Accounting Review, 53, 776-790.

Palmon, D., and L.J. Seidler, 1978b, "Postscript to Current Value Reporting of Real Estate Companies and a Possible Example of Market Inefficiency," Accounting Review, 54, 824.

Ro, B., 1981, "The Disclosure of Replacement Cost Accounting Data and Its Effect on Transaction Volume," Accounting Review, 56, 70-84.

Rozeff, M. S., and M. A. Zaman, 1988, "Market Efficiency and Insider Trading: New Evidence," Journal of Business, 61, 25-44.

Weinstein, M., 1977, "The Effect of a Rating Change Announcement on Bond Price," Journal of Financial Economics, 5, 329-350. 